\title{
Phycologia Phycologia
}

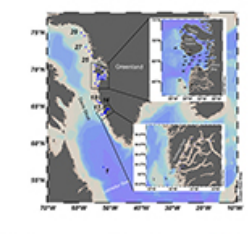

\section{Attributing Ceratocorys, Pentaplacodinium and Protoceratium to Protoceratiaceae (Dinophyceae), with descriptions of Ceratocorys malayensis sp. nov. and Pentaplacodinium usupianum sp. nov.}

\section{Zhaohe Luo, Zhen Fei Lim, Kenneth Neil Mertens, Bernd Krock, Sing Tung Teng, Toh Hii Tan, Chui Pin Leaw, Po Teen Lim \& Haifeng Gu}

To cite this article: Zhaohe Luo, Zhen Fei Lim, Kenneth Neil Mertens, Bernd Krock, Sing Tung Teng, Toh Hii Tan, Chui Pin Leaw, Po Teen Lim \& Haifeng Gu (2020) Attributing Ceratocorys, Pentaplacodinium and Protoceratium to Protoceratiaceae (Dinophyceae), with descriptions of Ceratocorys malayensis sp. nov. and Pentaplacodinium usupianum sp. nov., Phycologia, 59:1, 6-23, DOI: $10.1080 / 00318884.2019 .1663693$

To link to this article: https://doi.org/10.1080/00318884.2019.1663693

View supplementary material $\widetilde{ }$ 


\title{
Attributing Ceratocorys, Pentaplacodinium and Protoceratium to Protoceratiaceae (Dinophyceae), with descriptions of Ceratocorys malayensis sp. nov. and Pentaplacodinium usupianum sp. nov.
}

\author{
Zhaohe Luo ${ }^{1}$, Zhen Fei Lim² ${ }^{2}$ Kenneth Neil Mertens ${ }^{3}$, Bernd Krock ${ }^{4}$, Sing Tung Teng ${ }^{5}$, Toh Hil Tan ${ }^{2}$, Chui Pin Leaw ${ }^{2}$, Po Teen Lim², \\ AND HaIFENG Gu (D) ${ }^{1}$ \\ ${ }^{1}$ Third Institute of Oceanography, Ministry of Natural Resources, Xiamen 361005, China \\ ${ }^{2}$ Bachok Marine Research Station, Institute of Ocean and Earth Sciences, University of Malaya, Bachok 16310, Malaysia \\ ${ }^{3}$ Ifremer, LER BO, Station de Biologie Marine, Place de la Croix, BP40537, Concarneau CEDEX F-29185, France \\ ${ }^{4}$ Alfred Wegener Institute for Polar and Marine Research, Ecological Chemistry, Am Handelshafen 12, Bremerhaven D-27570, Germany \\ ${ }^{5}$ Faculty of Resource Science and Technology, Universiti Malaysia Sarawak, Kota Samarahan 94300, Malaysia
}

\begin{abstract}
The gonyaulacean family Protoceratiaceae is characterised by five precingular plates. It currently encompasses the type genus Ceratocorys and the fossil genus Atopodinium. Fourteen strains of Ceratocorys, Pentaplacodinium, and Protoceratium were established from Malaysian and Hawaiian waters, and their morphologies were examined using light and scanning electron microscopy. Two new species, Ceratocorys malayensis sp. nov. and Pentaplacodinium usupianum sp. nov., were described from Malaysian waters. They share a Kofoidean plate formula of Po, Pt, 3', 1a, 6", 6C, 6S, 5'", 1p, 1'"'. Ceratocorys malayensis has a short first apical plate $\left(1^{\prime}\right)$ with no direct contact with the anterior sulcal plate (Sa) whereas Pentaplacodinium usupianum had a parallelogram-shaped 1' plate which often contacted the Sa plate. The genera Ceratocorys and Pentaplacodinium were emended accordingly to incorporate species bearing five or six precingular plates. The Protoceratium strain from Hawaii was morphologically similar to $P$. reticulatum, but differed in the lack of a ventral pore in plate $1^{\prime}$ and slight or lack of contact between plates $1^{\prime}$ and $\mathrm{Sa}$, and is here designated as $P$. cf. reticulatum. The maximum-likelihood and Bayesian inference analyses based on SSU, LSU and ITS ribosomal DNA sequences revealed that these three genera are monophyletic and form a well-resolved group. Our results support Protoceratium and Pentaplacodinium as members of the family Protoceratiaceae, characterised by the presence of one anterior intercalary plate. Seven strains of Protoceratium cf. reticulatum, Ceratocorys malayensis and Pentaplacodinium usupianum were examined for yessotoxin production by LC-MS/MS but none produced a detectable amount of toxin.
\end{abstract}

ARTICLE HISTORY

Received 22 May 2019

Accepted 02 September 2019

Published online 16 October 2019

\section{KEYWORDS}

Ceratocoryaceae; Gonyaulacaceae; Molecular phylogeny; Protoceratium reticulatum; Yessotoxin

\section{INTRODUCTION}

The Gonyaulacales is a major order of dinophytes that is subdivided into five suborders based only on morpho-anatomy (Fensome et al. 1993). One of these, Gonyaulacineae, encompasses two extant families, Gonyaulacaceae and Ceratocorythaceae, and one fossil family, Areoligeraceae. Ceratocorythaceae have five precingular plates, L-type ventral organisation and strong dextral torsion, whereas Gonyaulacaeae have six precingular plates, L- to S-type ventral organisation and sinistral to dextral torsion (Fensome et al. 1993). Thus, the key difference between Gonyaulacaceae and Ceratocorythaceae is the number of precingular plates (six versus five). The Gonyaulacaceae was subdivided further into three subfamilies by Fensome et al. (1993): Cribroperidinioideae (with L-type ventral organisation and dextral torsion), Leptodinioideae (with L-type ventral organisation and sinistral or neutral torsion), and Gonyaulacoideae (with S-type ventral organisation and neutral torsion). The criteria used to distinguish subfamilies of Gonyaulacaceae, however, were sometimes inconsistent (Helenes 2000) or gradational in nature, and, in some instances, tentative (Fensome et al. 1993).

Currently, the Ceratocorythaceae include only the extant genus Ceratocorys F.Stein and the fossil genus Atopodinium Drugg (Fensome et al. 1993). Ceratocorys is characterised by three apical plates, one small anterior intercalary plate and five precingular plates $\left(3^{\prime}, 1 \mathrm{a}, 5^{\prime \prime}\right)$. The third Kofoidean precingular plate in Ceratocorys is considered homologous to both the third and fourth precingular plates in other gonyaulacoid dinoflagellate genera (Mertens et al. 2018b). Additionally, cells of Ceratocorys are often characterised by an angular body, shorter epitheca relative to hypotheca, small to large spines on the hypotheca, and heavily ornamented theca (Carbonell-Moore 1996). Twelve Ceratocorys species have been described, e.g. Ceratocorys anacantha M.C. Carbonell-Moore, C. armata (Schütt) Kofoid, C. bipes (Cleve) Kofoid, C. horrida Stein; all are exclusively marine and found only in tropical and subtropical waters (Carbonell- 
Moore 1996; Graham 1942). However, sequences of Ceratocorys are available for only three species: Ceratocorys armata, C. horrida, and C. gourretii, which share high nucleotide similarity for the SSU (100\%) and LSU ribosomal gene markers (> 99\%; Mertens et al. 2018b).

Pentaplacodinium Mertens, Carbonell-Moore, Pospelova \& Head was established for strains formerly identified as Protoceratium reticulatum (Claparède \& Lachmann) Bütschli (Mertens et al. 2018b). Salgado et al. (2018) considered this species to belong to Ceratocorys. Mertens et al. (2018a, b) disagreed because of the insert type epithecal configuration in these strains, unlike the episert type in Ceratocorys horrida, the type species of Ceratocorys. However, episert (type I) was also reported in Pentaplacodinium saltonense (Salgado et al. 2018, as Ceratocorys mariaovidiorum). Pentaplacodinium is a sister clade of Ceratocorys in the molecular phylogeny based on ribosomal DNA sequence, but has not been assigned to a family.

Protoceratium reticulatum is a common dinoflagellate originally described from Bergen Fjord, Norway, by Claparède \& Lachmann (1858) as Peridinium reticulatum Claparède \& Lachmann. Protoceratium Bergh was erected by Bergh (1881, p. 242) with $P$. aceros as the type species (fig. 36) collected at Strib, Denmark. The plate formula for $P$. reticulatum was first provided by Wołoszyńska (1929) as 4', 0a, 6", 6"', 1p, 1"'"', based on the Baltic Sea specimens. Reinecke (1967) described a similar species as Gonyaulax grindleyi Reinecke based on specimens from Elands Bay in Cape Town, South Africa, and provided its tabulation as 3', 1a, 6", 6"', 1p, 1"'". The difference between Protoceratium reticulatum and Gonyaulax grindleyi was considered to be the number of apical plates and anterior intercalary plates. Hansen et al. (1997) restudied specimens close to the type locality of $P$. aceros and confirmed that the epithecal tabulations can be $3^{\prime}, 1 \mathrm{a}, 6^{\prime \prime}$ or 4', 0a, 6". Therefore, Hansen et al. (1997) concluded that $P$. reticulatum, $P$. aceros and G. grindleyi were conspecific (Hansen et al. 1997). Eleven other Protoceratium species have been described, e.g., Protoceratium splendens Meunier, Protoceratium aculeatum (von Stein) Schiller, Protoceratium areolatum Kofoid and Protoceratium spinulosum (Murray \& Whitting) Schiller (e.g. Schiller 1937, p. 322-326). Of these species, only $P$. reticulatum has an available sequence.

Protoceratium reticulatum was questionably assigned to subfamily Cribroperidinioideae of Gonyaulacaceae by Fensome et al. (1993); however, molecular phylogenetic inference showed that $P$. reticulatum was closely related to Ceratocorys (Orr et al. 2012; Saldarriaga et al. 2004). Kawai \& Nakayama (2015) suggested using Protoceratiaceae instead of Ceratocorythaceae. Sequences of several unidentified strains from Malaysia and Hawaii were previously reported by Mertens et al. (2018b). The morphology of these and other related strains of Ceratocorys and Pentaplacodinium are investigated in this study in detail. Furthermore, to address the phylogenetic relationships among Protoceratium, Ceratocorys and Pentaplacodinium, two SSU, five partial LSU and eleven ITS rDNA sequences were determined for the cultured strains and the molecular phylogeny was inferred.

\section{MATERIAL AND METHODS}

\section{Sample collection and treatment}

Surface sand samples (upper $5 \mathrm{~cm}$ ) were collected by SCUBA divers using plastic bottles from Semariang and Talang-Talang Island (Sarawak), Rawa Island (Terengganu), Malaysia, from 2010 to 2016 (Table 1). The samples were rinsed with filtered seawater and transferred into a polycarbonate bottle. Single motile ceratocorioid cells were immediately isolated by means of drawn-out Pasteur pipettes and using an Eclipse TS100 inverted microscope (Nikon, Tokyo, Japan) to establish clonal cultures. Thirteen strains of Ceratocorys and Pentaplacodinium were initially established in ES-DK medium at $25^{\circ} \mathrm{C}$ (Kokinos \& Anderson 1995) in Malaysia. These clonal cultures were transferred to Xiamen and maintained with $\mathrm{f} / 2-\mathrm{Si}$ medium (Guillard \& Ryther 1962$)$ at $20^{\circ} \mathrm{C}, 90 \mu \mathrm{mol}$ quanta $\cdot \mathrm{m}^{-2} \cdot \mathrm{s}^{-1}$ under a $12: 12$ h light: dark cycle (hereafter called 'standard culture conditions'). Plankton samples were also collected using a $20 \mu \mathrm{m}$ mesh-size plankton net by vertical and horizontal hauls at subsurface water of Rawa Island in 2016. The samples were fixed with $2 \%$ Lugol's solution, and later for SEM examination.

In Hawaii, sediment sampling was done using an Ekman grab in nearby Haleiwa Harbour on 4 March 2014 (water depth $3.0 \mathrm{~m}$; Table 1). The top $2 \mathrm{~cm}$ of sediment were sliced off and stored in the dark at $4{ }^{\circ} \mathrm{C}$ until further treatment. Approximately $5 \mathrm{~g}$ of wet sediment was mixed with $20 \mathrm{ml}$ of filtered seawater and stirred vigorously to dislodge detrital particles. The settled material was subsequently sieved through $120 \mu \mathrm{m}$ and $10 \mu \mathrm{m}$ filters. The $10-120 \mu \mathrm{m}$ fractions were rinsed with f/2-Si medium (Guillard \& Ryther 1962) and transferred into a 96-well culture plate. The culture plate was incubated under standard culture conditions. Single motile cells of Protoceratium were isolated with a micropipette with the above microscope and incubated in 96-well plate with $\mathrm{f} / 2$-Si medium under standard culture conditions. The strain HWYD1 was established in clonal cultures (Table 1).

\section{Morphological study of motile cells with microscopy}

Live cells were examined and photographed using a Zeiss Axio Imager light microscope (Carl Zeiss, Göttingen, Germany) equipped with a Zeiss Axiocam HRc digital camera and fluorescence. The cell size of 30 cells was measured using Axiovision v4.8.2 software at $\times 1000$ magnification. To observe shape and location of nuclei, cells were stained with 1:100,000 SYBR Green (Sigma Aldrich, St. Louis, Missouri, USA) for $1 \mathrm{~min}$, and photographed with the same Zeiss microscope with a Zeiss-38 filter set (excitation BP 470/40, beam splitter FT 495, emission BP 525/ 50). Chloroplast autofluorescence in live cells was observed using the above microscope equipped using a Chroma filter cube (emission filter ET480/20x, dichromatic mirror AT505dc, suppression filter AT515lp), and digitally photographed using a Zeiss Axiocam HRc digital camera.

For scanning electron microscopy (SEM), mid-exponential batch cultures were concentrated by centrifugation (Universal 320 R centrifuge, Hettich-Zentrifugen, Tuttlingen, Germany) at $850 \mathrm{~g}$ for $10 \mathrm{~min}$ at room temperature. Cells were fixed with 
Table 1. Information on isolates used in this study. Species designations, strain identification, origin, isolator, isolation date and yessotoxin. NA: not available.

\begin{tabular}{|c|c|c|c|c|c|c|c|c|}
\hline Species & Strains & $\begin{array}{l}\text { Latitude } \\
\qquad(\mathrm{N})\end{array}$ & $\begin{array}{l}\text { Longitude } \\
\text { (E) }\end{array}$ & Location & Isolator & $\begin{array}{l}\text { GenBank no. } \\
\text { (SSU/ITS/LSU) }\end{array}$ & $\begin{array}{l}\text { Isolation } \\
\text { date }\end{array}$ & Yessotoxin \\
\hline $\begin{array}{l}\text { Pentaplacodinium } \\
\text { usupianum }\end{array}$ & DBS01 & $1^{\circ} 36.00^{\prime}$ & $110^{\circ} 19.00^{\prime}$ & $\begin{array}{l}\text { Semariang, Sarawak, } \\
\text { Malaysia }\end{array}$ & Teng Sing Tung & $\begin{array}{l}\text { MN137905/ } \\
\text { MN137897/MN137902 }\end{array}$ & 21 Dec. 2016 & NA \\
\hline $\begin{array}{l}\text { Pentaplacodinium } \\
\text { usupianum }\end{array}$ & DBSO2 & $1^{\circ} 36.00^{\prime}$ & $110^{\circ} 19.00^{\prime}$ & $\begin{array}{l}\text { Semariang, Sarawak, } \\
\text { Malaysia }\end{array}$ & Teng Sing Tung & $\begin{array}{l}\text { MN137906/ } \\
\text { MN137898/MN137903 }\end{array}$ & 21 Dec. 2016 & NA \\
\hline $\begin{array}{l}\text { Pentaplacodinium } \\
\text { usupianum }\end{array}$ & GgSM01 & $1^{\circ} 36.00^{\prime}$ & $110^{\circ} 19.00^{\prime}$ & $\begin{array}{l}\text { Semariang, Sarawak, } \\
\text { Malaysia }\end{array}$ & Tan Toh Hii & $\begin{array}{l}\text { MG646302/ } \\
\text { MN137888/MG646324 }\end{array}$ & 08 Aug. 2010 & None \\
\hline $\begin{array}{l}\text { Pentaplacodinium } \\
\text { usupianum }\end{array}$ & GgSM03 & $1^{\circ} 36.00^{\prime}$ & $110^{\circ} 19.00^{\prime}$ & $\begin{array}{l}\text { Semariang, Sarawak, } \\
\text { Malaysia }\end{array}$ & Tan Toh Hii & $\begin{array}{l}\text { MG646303/ } \\
\text { MN137889/- }\end{array}$ & 22 Sep. 2010 & NA \\
\hline $\begin{array}{l}\text { Pentaplacodinium } \\
\text { usupianum }\end{array}$ & GgSM07 & $1^{\circ} 36.00^{\prime}$ & $110^{\circ} 19.00^{\prime}$ & $\begin{array}{l}\text { Semariang, Sarawak, } \\
\text { Malaysia }\end{array}$ & Tan Toh Hii & $\begin{array}{l}\text { MG646304/ } \\
\text { MN137890/MG646325 }\end{array}$ & 17 Jan. 2013 & None \\
\hline $\begin{array}{l}\text { Pentaplacodinium } \\
\text { usupianum }\end{array}$ & GgSM10 & $1^{\circ} 36.00^{\prime}$ & $110^{\circ} 19.00^{\prime}$ & $\begin{array}{l}\text { Semariang, Sarawak, } \\
\text { Malaysia }\end{array}$ & Kam Bao Juan & $\begin{array}{l}\text { MG646305/ } \\
\text { MN137897/MG646326 }\end{array}$ & 17 Jan. 2013 & None \\
\hline $\begin{array}{l}\text { Pentaplacodinium } \\
\text { usupianum }\end{array}$ & GgSM11 & $1^{\circ} 36.00^{\prime}$ & $110^{\circ} 19.00^{\prime}$ & $\begin{array}{l}\text { Semariang, Sarawak, } \\
\text { Malaysia }\end{array}$ & Kam Bao Juan & $\begin{array}{l}\text { MG646306/ } \\
\text { MN137897/MG646327 }\end{array}$ & 17 Jan. 2013 & None \\
\hline $\begin{array}{l}\text { Ceratocorys } \\
\text { malayensis }\end{array}$ & A10-49-A55 & $5^{\circ} 57.70^{\prime}$ & $102^{\circ} 40.88^{\prime}$ & $\begin{array}{l}\text { Rawa Island, } \\
\text { Terrenganu, Malaysia }\end{array}$ & Lim Zhen Fei & $\begin{array}{l}\text { MN137904/ } \\
\text { MN137896/MN137899 }\end{array}$ & 17 May 2016 & None \\
\hline $\begin{array}{l}\text { Ceratocorys } \\
\text { malayensis }\end{array}$ & A10-49-A56 & $5^{\circ} 57.70^{\prime}$ & $102^{\circ} 40.88^{\prime}$ & $\begin{array}{l}\text { Rawa Island, } \\
\text { Terrenganu, Malaysia }\end{array}$ & Lim Zhen Fei & -/-/MN137901 & 17 May 2016 & NA \\
\hline $\begin{array}{l}\text { Ceratocorys } \\
\text { malayensis }\end{array}$ & A10-49-A61 & $5^{\circ} 57.70^{\prime}$ & $102^{\circ} 40.88^{\prime}$ & $\begin{array}{l}\text { Rawa Island, } \\
\text { Terrenganu, Malaysia }\end{array}$ & Lim Zhen Fei & -/-/MN137900 & 17 May 2016 & None \\
\hline $\begin{array}{l}\text { Ceratocorys } \\
\text { malayensis }\end{array}$ & PrTT01 & $1^{\circ} 55.02^{\prime}$ & $109^{\circ} 46.47^{\prime}$ & $\begin{array}{l}\text { Talang-Talang Island, } \\
\text { Sarawak, Malaysia }\end{array}$ & Teng Sing Tung & $\begin{array}{l}\text { MG646307/ } \\
\text { MN137893/- }\end{array}$ & 28 Mar. 2013 & NA \\
\hline $\begin{array}{l}\text { Ceratocorys } \\
\text { malayensis }\end{array}$ & PrTT02 & $1^{\circ} 55.02^{\prime}$ & $109^{\circ} 46.47^{\prime}$ & $\begin{array}{l}\text { Talang-Talang Island, } \\
\text { Sarawak, Malaysia }\end{array}$ & Teng Sing Tung & $\begin{array}{l}\text { MG646308/ } \\
\text { MN137895/- }\end{array}$ & 28 Mar. 2013 & NA \\
\hline $\begin{array}{l}\text { Ceratocorys } \\
\text { malayensis }\end{array}$ & PrTT03 & $1^{\circ} 55.02^{\prime}$ & $109^{\circ} 46.47^{\prime}$ & $\begin{array}{l}\text { Talang-Talang Island, } \\
\text { Sarawak, Malaysia }\end{array}$ & Teng Sing Tung & $\begin{array}{l}\text { MG646309/ } \\
\text { MN137894/- }\end{array}$ & 28 Mar. 2013 & NA \\
\hline $\begin{array}{l}\text { Protoceratium cf. } \\
\text { reticulatum }\end{array}$ & HWYD1 & $21^{\circ} 35.65^{\prime}$ & $-158^{\circ} 6.00^{\prime}$ & $\begin{array}{l}\text { Haleiwa Harbour, north } \\
\text { coast of O'ahu, USA }\end{array}$ & $\begin{array}{l}\text { Anne de Vernal and } \\
\text { Geneviève Vautour }\end{array}$ & $\begin{array}{l}\text { MG646320/MG646295/ } \\
\text { MG646298 }\end{array}$ & 04 Mar. 2014 & None \\
\hline
\end{tabular}

$2.5 \%$ glutaraldehyde for $3 \mathrm{~h}$ at $8{ }^{\circ} \mathrm{C}$, rinsed with Milli-Q water twice and post-fixed with $1 \% \mathrm{OsO}_{4}$ overnight at $8{ }^{\circ} \mathrm{C}$. The supernatant was removed and settled cells were transferred to a coverslip coated with poly-L-lysine (molecular weight $70,000-150,000)$. Cells attached to the coverslip were rinsed in Milli-Q water twice. Samples were then dehydrated in a graded ethanol series $(10,30,50,70,90$ and $3 \times$ in $100 \%, 10$ min at each step), critical point dried (K850 Critical Point Dryer, Quorum/ Emitech, West Sussex, UK), sputter-coated with gold, and examined using a Zeiss Sigma FE (Carl Zeiss Inc., Oberkochen, Germany) scanning electron microscope. Labelling of tabulation follows a modified Kofoid system that recognises homologs (e.g., Fensome et al. 1993); sulcal plate labelling follows Balech (1980).

\section{PCR amplifications and sequencing}

Total algal DNA of Ceratocorys, Pentaplacodinium and Protoceratium was extracted from $10 \mathrm{ml}$ of exponentially growing cultures using a MiniBEST Universal DNA Extraction Kit (Takara, Tokyo, Japan) according to manufacturer's protocol. PCR amplifications were carried out using $1 \times$ PCR buffer, $50 \mu \mathrm{M}$ dNTP mixture, $0.2 \mu \mathrm{M}$ of each primer, 10 ng of template genomic DNA, and $1 \mathrm{U}$ of ExTaq DNA Polymerase (Takara, Tokyo, Japan) in $50 \mu$ reactions. The SSU rDNA was amplified using the primer pair PRIMER A/ PRIMER B (Medlin et al. 1988). LSU rDNA was amplified using the primer pair D1R/28-1483R (Daugbjerg et al. 2000; Scholin et al. 1994). Total ITS1-5.8S-ITS2 was amplified using the primer pair ITSA/ITSB (Adachi et al. 1996). The thermal cycle procedure was 4 min at $94{ }^{\circ} \mathrm{C}$, followed by 30 cycles of $1 \mathrm{~min}$ at $94{ }^{\circ} \mathrm{C}, 1 \mathrm{~min}$ at $45^{\circ} \mathrm{C}, 1 \mathrm{~min}$ at $72^{\circ} \mathrm{C}$, and final extension of $7 \mathrm{~min}$ at $72{ }^{\circ} \mathrm{C}$ with a Mastercycler (Eppendorf, Hamburg, Germany). PCR product was purified using a DNA purification kit (Shengong, Shanghai, China) and sequenced directly in both directions on an ABI PRISM 3730XL (Applied Biosystems, Foster City, California, USA) following manufacturer's instructions. Newly obtained sequences were deposited in GenBank with accession numbers MN137888 to MN137906.

\section{Sequence alignment and phylogenetic analysis}

The newly obtained sequences of Ceratocorys, Pentaplacodinium and Protoceratium (SSU, partial LSU and ITS rDNA) were incorporated into independent datasets of closely related dinoflagellate sequences via taxon sampling in the NCBI GenBank nucleotide database. All sequences were aligned using MAFFT v7.110 (Katoh \& Standley 2013) online programme (http://mafft. cbrc.jp/alignment/server/) using the default settings. Alignments were manually checked with BioEdit v7.0.5 (Hall 1999). For Bayesian inference (BI), jModelTest (Posada 2008) was used to select the most appropriate model of molecular evolution using Akaike Information Criterion (AIC). Bayesian reconstruction of the data matrix was performed using MrBayes 3.2 (Ronquist \& Huelsenbeck 2003) with the best-fitting substitution model $(\mathrm{GTR}+\mathrm{G})$. Four Markov chain Monte Carlo (MCMC) chains 
were run for 1,000,000 generations, sampling every 100 generations. The first $10 \%$ of burn-in trees were discarded. A majority rule consensus tree was created to examine the posterior probabilities of each clade. Maximum-likelihood (ML) analyses were conducted with RaxML v7.2.6 (Stamatakis 2006) on the T-REX web server (Boc et al. 2012) using the model GTR+G. Node support was assessed with 1000 bootstrap replications.

The ITS1-5.8S-ITS2 sequences of Ceratocorys, Pentaplacodinium and Protoceratium species were aligned using MAFFT v7.110 (Katoh \& Standley 2013) online program with the default settings. Completed alignments were saved as NEXUS files and imported into PAUP* 4 b10 software (Swofford 2002) so that divergence rates could be estimated using simple uncorrected pairwise $(\mathrm{p})$ distance matrices.

\section{Yessotoxin analysis}

Cultures of two strains of Ceratocorys malayensis, four strains of Pentaplacodinium usupianum and one strain of Protoceratium cf. reticulatum were grown in 200-ml Erlenmeyer flasks under standard culture conditions. A total of $10^{5}-10^{6}$ cells at exponential phase (determined using sequential cell counts) were collected by centrifugation. Exponential phase was determined via linear regression of log-transformed cell count time series.

Algal pellets were ultrasonicated ( $70 \mathrm{~s}, 40 \%$ power, 70 cycles) in $100 \mu \mathrm{l}$ methanol with a sonotrode (model HP2070, Bandelin, Berlin, Germany). After homogenisation, samples were centrifuged $\left(16,000 \mathrm{~g}, 15 \mathrm{~min}, 4^{\circ} \mathrm{C}\right.$, Centrifuge 5415R, Eppendorf, Hamburg, Germany) and supernatants were transferred to spinfilters (pore-size $0.45 \mathrm{~mm}$, Millipore Ultrafree, Eschborn, Germany) and centrifuged for $30 \mathrm{~s}$ at $3220 \mathrm{~g}$. Filtrates were transferred into HPLC vials (Agilent Technologies, Waldbronn, Germany) and stored at $-20{ }^{\circ} \mathrm{C}$ until analysis.

Yessotoxin measurements were carried out on a triple quadruple mass spectrometer (API 4000 QTrap, Sciex, Darmstadt, Germany) as detailed in Sala-Pérez et al. (2016). In brief, separation was performed on a reversed-phase C8 column $(50 \times 2 \mathrm{~mm}, 3 \mu \mathrm{m})$ at a flow rate of $0.3 \mathrm{ml} \mathrm{min}^{-1}$ using an elution gradient with two eluents, water and acetonitrile/methanol, $(1: 2 \mathrm{v} / \mathrm{v})$. Yessotoxins were detected in the selected reaction monitoring (SRM) mode and 25 transitions were used (Sala-Pérez et al. 2016).

\section{RESULTS}

Family Protoceratiaceae Lindemann 1928

\section{Ceratocorys malayensis Z.Luo, P.T.Lim \& H.Gu sp. nov.} Figs 1-22

DESCRIPTION: Cells heavily reticulated, 40.2-58.0 $\mu \mathrm{m}$ long and 40.9-54.6 $\mu \mathrm{m}$ wide, with rounded epitheca and hypotheca with several short antapical spines; ratio of epitheca/hypotheca around 0.84 . Cells with numerous radiating chloroplasts and a $\mathrm{U}$-shaped posterior nucleus. Cells with plate formula Po, Pt, 3', 1a, 6", 6C, 6S, 5", 1p, 1'"' and with L-type ventral organisation and sinistral torsion. Pore plate oval with a $\lambda$ shaped cover plate (Pt). First apical plate short and narrow, not contacting plate Sa (episert type I) with a ventral pore at the border with plate $3^{\prime}$.
HOLOTYPE: SEM stub from strain A10-49-A55 designated as TIO201901, deposited at Third Institute of Oceanography, Ministry of Natural Resources, Xiamen, 361005, China.

TYPE LOCALITY: Rawa Island, Terengganu, Malaysia (South China Sea, $5^{\circ}$ $\left.57.70^{\prime} \mathrm{N} ; 102^{\circ} 40.88^{\prime} \mathrm{E}\right)$. Collection date: 17 May 2016.

HABITAT: Marine, sand.

ETYMOLOGY: The epithet 'malayensis' derived from Malay Archipelago, where the species was recovered.

GENBANK ACCESSIONS: MN137904, MN137899 and MN137896, the nuclear-encoded SSU, LSU and ITS rDNA sequences of strain A10-49A55.

DISTRIBUTION: Terengganu and Sarawak of Malaysia.

\section{Morphology}

Strains of Ceratocorys malayensis were morphologically indistinguishable from each other. Cells of strain A10-49-A55 were $40.2-58.0 \mu \mathrm{m}$ long $(49.2 \pm 4.9 \mu \mathrm{m}, n=30), 40.9-54.6 \mu \mathrm{m}$ wide ( $46.6 \pm 3.9 \mu \mathrm{m}, n=30$ ), and brownish cell contents due to the presence of chloroplasts (Fig. 1). Cells had a rounded epitheca and hypotheca with several short spines 3.0-4.1 $\mu \mathrm{m}$ long at the antapical end (Fig. 2). The epitheca was smaller than the hypotheca with the ratio of epitheca/hypotheca ranging from 0.72 to $0.98(0.84 \pm 0.08, \mathrm{n}=23)$ (Figs $1,2,7$ and 8$)$. Numerous chloroplasts radiated from the central part of the cell (Fig. 3). The nucleus was U-shaped and located in cell posterior (' $\mathrm{N}$ ' in Fig. 4).

Thecae displayed plate formula Po, Pt, 3', 1a, 6", 6C, 6S, $5^{\prime \prime \prime}, 1 \mathrm{p}, 1^{\prime \prime \prime \prime}$ (Figs 1-18), and had a sexiform gonyaulacoid tabulation (cf. Fensome et al. 1993, fig. 64B; Figs 10, 13) with a L-type ventral organisation (cf. Fensome et al. 1993, figs $82 \mathrm{~A}, \mathrm{C})$ (Figs 9, 17) and sinistral torsion (cf. Fensome et al. 1993, text-fig. 83C) (Fig. 8). The plates were heavily reticulated with one pore inside each reticulation, although two or more pores might occur in reticulations adjacent to a suture. The reticulations were weakly expressed on the sulcus and cingulum (Figs 11, 12). The pore plate (Po) was oval with a $\lambda$-shaped cover plate $(\mathrm{Pt})$ and perforated with approximately 10 pores (Figs 15,16$)$. The first apical plate $\left(1^{\prime}\right)$ was asymmetric and narrowed posteriorly with a ventral pore on its right side (Fig. 18). Plate 1' was short and narrow and did not contact anterior sulcal plate (Sa; Figs 6, 17), i.e., episert type I (Paez-Reyes \& Head 2013). The second and third apical plates $\left(2^{\prime}, 3^{\prime}\right)$ were much larger and irregularly shaped (Figs $6,14,17$ ). The anterior intercalary plate was small and pentagonal without contacting the pore plate (Figs 6, 9, 14). The precingular series consisted of six plates, with $3^{\prime \prime}$ and 4 " much smaller than the rest (Figs 5, 9, 14, 17). The cingulum was descending, lined with narrow lists, and comprised six cingular plates with two rows of pores along their anterior and posterior margins (Figs 8, 11, 12). The ends of the cingulum did not overhang and were displaced by twice the cingulum width (Fig. 12).

The sulcus was narrow anteriorly, slightly widened posteriorly, and consisted of six plates. The Sa plate was relatively small and intruded between plates 1" and 6" without contacting plate $1^{\prime}$. The anterior left sulcal plate (Ssa) was similar in size to 

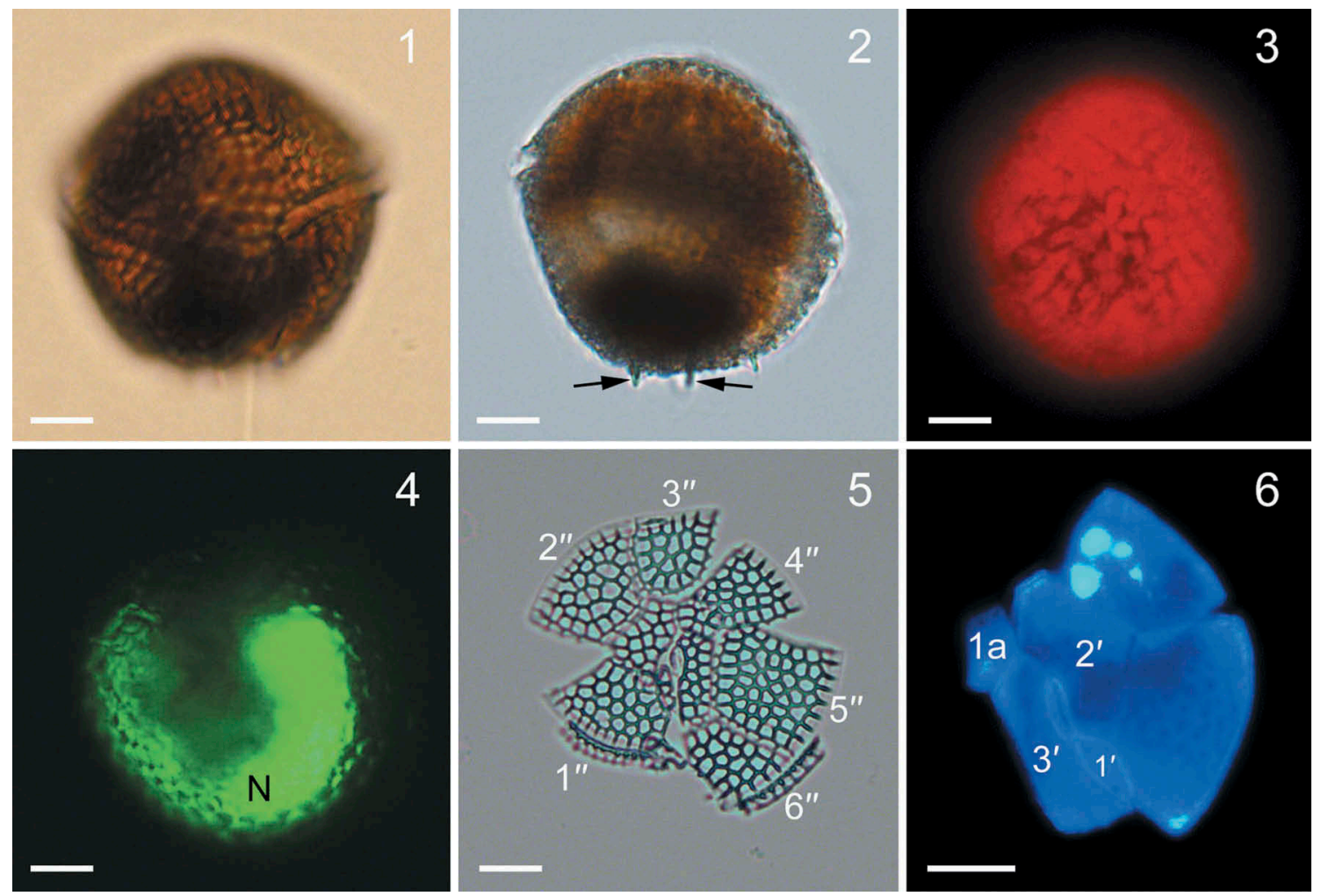

Figs 1-6. Light micrographs of live cells of Ceratocorys malayensis strain A10-49-A55. Scale bar $=10 \mu \mathrm{m}$.

Fig. 1. Ventral view showing gross morphology and cingulum displacement.

Fig. 2. Lateral view with several spines in hypotheca (arrows).

Fig. 3. Cell with numerous autofluorescent chloroplasts.

Fig. 4. SYBR Green-stained cell, with U-shaped nucleus (N).

Fig. 5. Apical view with six precingular plates.

Fig. 6. Epithecal plates stained with calcofluor showing three apical plates $\left(1^{\prime}-3^{\prime}\right)$ and one anterior intercalary plate (1a).

the anterior right sulcal plate (Sda). The left posterior sulcal (Ssp) was larger than the posterior right sulcal (Sdp). The large posterior sulcal (Sp) was at the bottom of the sulcus, with pores lined up along the left suture with plate $1^{\prime \prime \prime \prime}$ (Fig. 12).

The hypotheca comprised five postcingular plates and one antapical plate. Plate ${ }^{\star} 2^{\prime \prime \prime}$ was triangular and the smallest in the series (Fig. 13). All other postcingular plates were large, although ${ }^{*} 6$ "' was relatively smaller (Fig. 10). The posterior intercalary plate (1p) was small and elongated, located adjacent to plate $\mathrm{Sp}$ with a conspicuous flange on its right margin (Fig. 13). The antapical plate $\left(1^{\prime \prime \prime \prime}\right)$ was six-sided and large, located in the middle of the hypotheca with several spines emerging from the margins (Figs 10, 13). Cells of C. malayensis from the field had morphology identical to those in culture (Figs S1, S2). Schematic drawings of C. malayensis are provided (Figs 19-22). Cysts were not observed in cultures.

Pentaplacodinium usupianum Z.Luo, Leaw \& H.Gu sp. nov. Figs 23-39

DESCRIPTION: Thecae reticulated more heavily on hypotheca than on epitheca, 26.6-31.3 $\mu \mathrm{m}$ long and 22.7-27.7 $\mu \mathrm{m}$ wide. Cells with conical epitheca and rounded hypotheca with similar size. Cells with numerous radiating chloroplasts and U-shaped posterior nucleus. Thecae with plate formula Po, Pt, 3', 1a, 6", 6C, 6S, 5"', 1p, 1'"' and an L-type ventral organisation and neutral torsion; pore plate oval. The first apical plate a parallelogram slightly contacting plate Sa (insert type).

HOLOTYPE: SEM stub from strain DBS02 designated as TIO201902, deposited at Third Institute of Oceanography, Ministry of Natural Resources, Xiamen, 361005, China.

TYPE LOCALITY: Semariang, Sarawak, Malaysia (South China Sea, $1^{\circ}$ $\left.36.00^{\prime \prime} \mathrm{N} ; 110^{\circ} 19.00^{\prime} \mathrm{E}\right)$. Collection date: 21 December 2016.

HABITAT: Marine, sand.

ETYMOLOGY: The epithet 'usupianum' is in honour of Gires Usup, who did pioneering work on harmful algal blooms in Malaysia.

GENBANK ACCESSIONS: MN137906, MN137903 and MN137898, the nuclear-encoded SSU, LSU and ITS rDNA sequences of strain DBS02.

DISTRIBUTION: Sarawak, Malaysia.

\section{Morphology}

Strains of Pentaplacodinium usupianum were morphologically indistinguishable from each other. Cells of strain DBS02 were $26.6-31.3 \mu \mathrm{m}$ long $(28.8 \pm 1.3 \mu \mathrm{m}, \mathrm{n}=30)$ and $22.7-27.7 \mu \mathrm{m}$ wide $(24.7 \pm 1.4 \mu \mathrm{m}, \mathrm{n}=30)$. Cells were brownish due to presence of chloroplasts (Fig. 23). Cells had a conical epitheca and rounded hypotheca with several spines $1.0-1.2 \mu \mathrm{m}$ long at antapical end (Figs 23-26, 29). These 

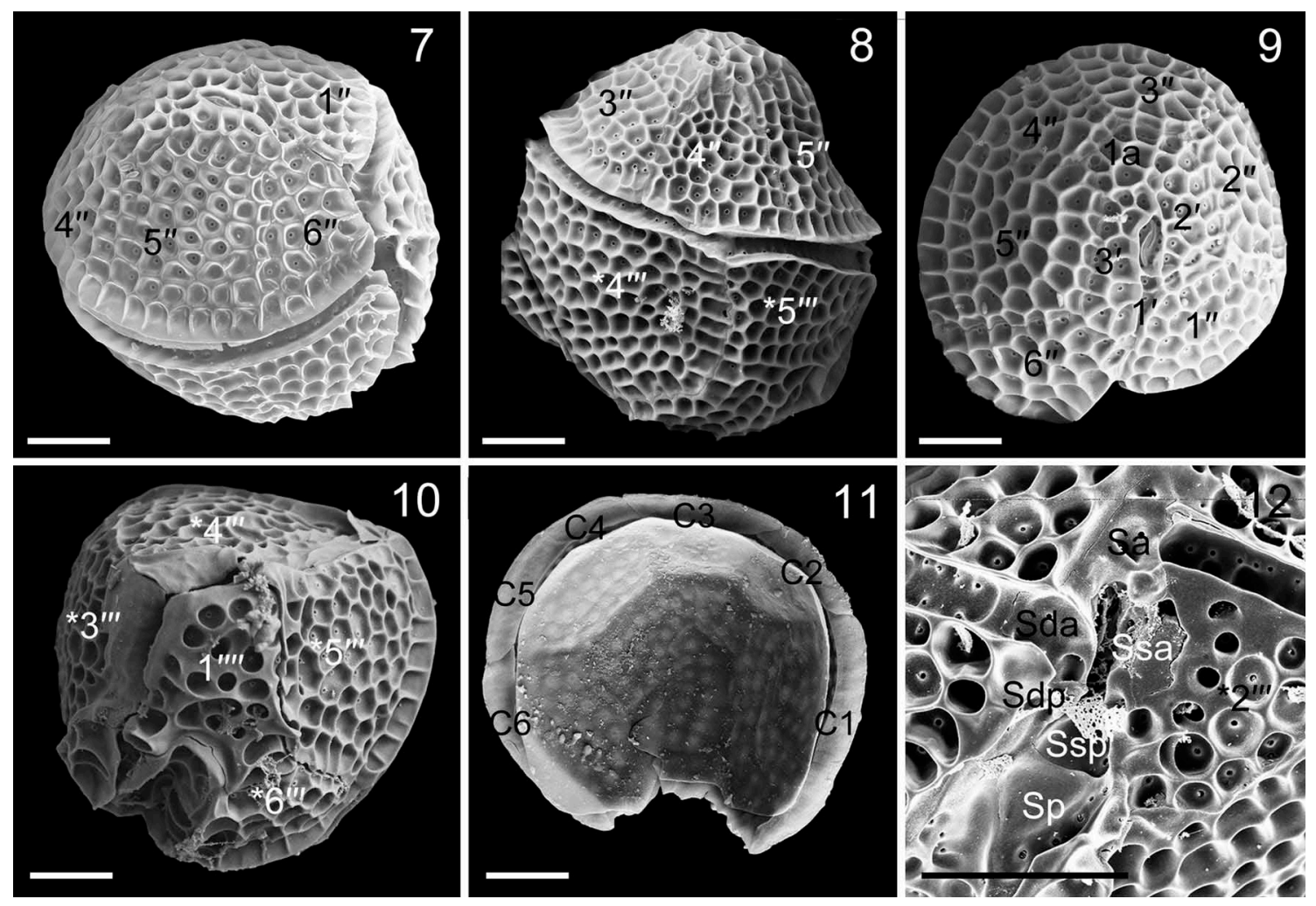

Figs 7-12. Scanning electron micrographs of Ceratocorys malayensis strain A10-49-A55. Scale bar $=10 \mu \mathrm{m}$.

Fig. 7. Oblique apical view showing cingulum displacement.

Fig. 8. Dorsal view showing precingular plates $\left(3^{\prime \prime}-5^{\prime \prime}\right)$ and postcingular plates $\left({ }^{*} 4^{\prime \prime \prime},{ }^{*} 5^{\prime \prime \prime}\right)$ with evident sinistral torsion.

Fig. 9. Apical view showing three apical plates $\left(1^{\prime}-3^{\prime}\right)$, one anterior intercalary (1a) plate and six precingular plates $\left(1^{\prime \prime}-6^{\prime \prime}\right)$.

Fig. 10. Antapical view showing four postcingular plates $\left({ }^{*} 3^{\prime \prime \prime}-{ }^{*} 6^{\prime \prime \prime}\right)$ and one antapical plate $\left(1^{\prime \prime \prime \prime}\right)$.

Fig. 11. Cingulum showing six cingular plates (C1-C6).

Fig. 12. Sulcus showing anterior sulcal plate (Sa), anterior left sulcal plate (Ssa), anterior right sulcal plate (Sda), posterior left sulcal plate (Ssp), posterior right sulcal plate (Sdp) and posterior sulcal plate (Sp).

antapical spines were not always present (Fig. 31). The cingulum was situated in the equatorial part of the cell (Fig. 24). The cells showed numerous chloroplasts radiating from the central part of the cell (Fig. 27). The nucleus was U-shaped and posterior (' $\mathrm{N}$ ' in Figs 26, 28).

Thecae displayed plate formula Po, Pt, $3^{\prime}, 1 \mathrm{a}, 6^{\prime \prime}, 6 \mathrm{C}, 6 \mathrm{~S}, 5^{\prime \prime \prime}$, $1 \mathrm{p}, 1^{\prime \prime \prime \prime}$ (Figs 29-35), and had a sexiform gonyaulacoid tabulation (Fig. 31) with an L-type ventral organisation (Fig. 29) and neutral torsion (Figs S3, S4). The plates were more heavily reticulated on the hypotheca than the epitheca, with one pore inside each reticulation (Figs 29-31). The pore plate (Po) was oval to elliptical with a $\lambda$-shaped cover plate $(\mathrm{Pt})$ and perforated by around seven pores (Figs 33, 34). The first apical plate (1') was parallelogram-shaped, lacked a ventral pore, and slightly contacted the anterior sulcal plate (Sa; Figs 25, 29), i.e., the insert type (Fensome et al. 1996, text-fig. 34). The second and third apical plates $\left(2^{\prime}, 3^{\prime}\right)$ were slightly larger and irregularly shaped (Figs 30,33). The anterior intercalary plate was fivesided and contacted plates 2', 3', 3", 4" and 5" (Figs 30, 33). The precingular series consisted of two four-sided plates $\left(2^{\prime \prime}, 4^{\prime \prime}\right)$ and four five-sided plates (1", 3", 5" and 6"; Figs 29, 30). Occasionally, five precingular plates were observed (Fig. S4). The cingulum was descending, lined with narrow lists, and comprised six cingular plates (Fig. 32). The ends of the cingulum did not overhang and were displaced by one cingulum width (Fig. 29).

The sulcus was narrow anteriorly and slightly widened posteriorly consisting of at least six plates. The Sa plate was large and hook-shaped, and intruded the epitheca to contact plate $1^{\prime}$. Occasionally, the Sa plate was small and did not contact plate $1^{\prime}$ (Figs S5, S6). The anterior left sulcal plate (Ssa) was slightly larger than the anterior right sulcal plate (Sda). The left posterior sulcal (Ssp) was similar in size to the posterior right sulcal (Sdp) (Fig. 35). The large posterior sulcal (Sp) was at the bottom of the sulcus, which bore lines of pores along its sutures with plates ${ }^{*} 6^{\prime \prime \prime}$ and $1^{\prime \prime \prime \prime}$ (Figs 29, 31).

The hypotheca comprised five postcingular plates and one antapical plate. Plate ${ }^{*} 2^{\prime \prime \prime}$ was triangular and the smallest in the series (Figs 29, 31). All other postcingular plates were trapezoid and large, although ${ }^{*} 6^{\prime \prime \prime}$ was relatively smaller (Figs 29,31$)$. The posterior intercalary plate (1p) was small and elongated, located adjacent to plate Sp (Fig. 29). The antapical plate $\left(1^{\prime \prime \prime \prime}\right)$ was six-sided and located in the middle of the hypotheca (Fig. 31). Schematic drawings of Pentaplacodinium usupianum are provided (Figs 36-39). Cysts were not observed in cultures. 

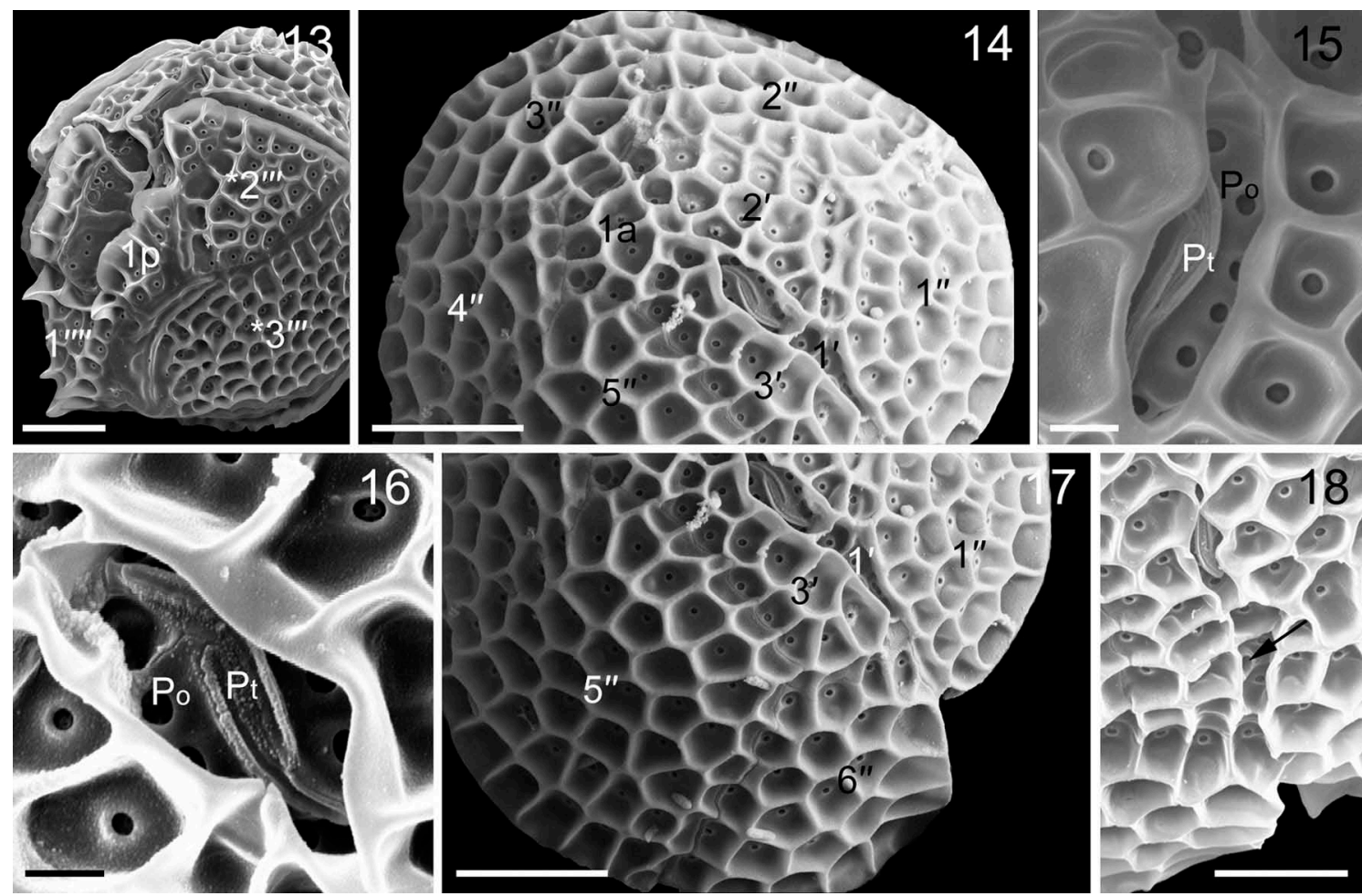

Figs 13-18. Scanning electron micrographs of Ceratocorys malayensis strain A10-49-A55.

Fig. 13. Left lateral view showing two postcingular plates $\left({ }^{*} 2^{\prime \prime \prime},{ }^{*} 3^{\prime \prime \prime}\right)$, posterior intercalary plate $(1 \mathrm{p})$ and antapical plate $\left(1^{\prime \prime \prime \prime}\right)$. Scale bar $=10 \mu \mathrm{m}$.

Fig. 14. Apical view with three apical plates $\left(1^{\prime}-3^{\prime}\right)$, one anterior intercalary (1a) plate and five of the six precingular plates $\left(1^{\prime \prime}-5^{\prime \prime}\right)$. Scale bar $=10 \mu \mathrm{m}$.

Figs 15, 16. Detail of oval pore plate (Po) with a $\lambda$-shaped cover plate (Pt) perforated by pores. Scale bar $=1 \mu \mathrm{m}$.

Fig. 17. Apical view showing first apical plates $\left(1^{\prime}\right)$, and wide contact between first and sixth precingular plates $\left(1^{\prime \prime}, 6^{\prime \prime}\right)$. Scale bar $=10 \mu \mathrm{m}$.

Fig. 18. Apical view showing first apical plate with ventral pore at its right margin (arrow). Scale bar $=10 \mu \mathrm{m}$.

\section{Protoceratium cf. reticulatum}

Figs $40-50$

\section{Morphology}

Cells of strain HWYD1 were 23.6-29.1 $\mu \mathrm{m}$ long $(26.2 \pm 1.1$ $\mu \mathrm{m}, \mathrm{n}=30)$ and $20.2-24.0 \mu \mathrm{m}$ wide $(21.9 \pm 0.9 \mu \mathrm{m}, \mathrm{n}=30)$. Cells were brownish due to chloroplasts (Figs 40, 41). The thecae had a rounded epitheca and hypotheca (Fig. 40). The cingulum was situated in the pre-equatorial part of the cell. Many chloroplasts radiated from the central part of the cell to form a network (Fig. 42). The nucleus was curved and located posteriorly ('N' in Fig. 43).

The thecae showed a plate formula of Po, Pt, 3', 1a, 6", 6C, 6S, $5^{\prime \prime \prime}, 1 \mathrm{p}, 1^{\prime \prime \prime \prime}$ (Figs 44-50), and had a sexiform gonyaulacoid tabulation (Fig. 48) with an L-type ventral organisation (Fig. 45 ) and dextral torsion (Figs 46, 47). The plates were reticulated with one pore inside each reticulation; the reticulation was weakly expressed on sulcus and cingulum (Figs 44-50). The pore plate was sigmoidal with a $\lambda$-shaped cover plate and perforated by around five pores (Fig. 49). The first apical plate (1') was rhombic, lacked a ventral pore, and contacted the anterior sulcal plate (Sa; Fig. 45), thus belonging to insert type. Sometimes, plate $1^{\prime}$ did not contact plate Sa, thus showing an episert type I (Fig. $44)$. The second and third apical plates $\left(2^{\prime}, 3^{\prime}\right)$ were much larger and irregularly shaped (Fig. 45). The anterior intercalary plate was five-sided which was either separated from or contacted the pore plate (Figs 45, 46). The precingular series consisted of 4 four-sided plates (2" and 4") and 4 five-sided plates (1", 3", 5" and $\left.6^{\prime \prime}\right)$ (Fig. 45). Occasionally, five precingular plates were observed (Fig. 46). The cingulum was descending, lined with narrow lists, and comprised six cingular plates (Figs 44, 47). The ends of the cingulum did not overhang and were displaced by one cingulum width (Fig. 44).

The sulcus was narrow anteriorly and slightly widened posteriorly. It consisted of six plates. The Sa plate was relatively large and hook-shaped, and intruded the epitheca either to contact plate 1' slightly (Fig. 45) or did not contact plate 1' (Fig. 44). The anterior left sulcal plate (Ssa) was similar in size with the anterior right sulcal plate (Sda). The left posterior sulcal (Ssp) was larger than the posterior right sulcal (Sdp) (Fig. 50). The large posterior sulcal plate (Sp) was at the bottom of the sulcus (Fig. 50).

The hypotheca comprised five postcingular plates and one antapical plate. All postcingular plates were trapezoidal and large except that ${ }^{\star} 3^{\prime \prime \prime}$ was five-sided, and ${ }^{\star} 2^{\prime \prime \prime}$ and ${ }^{\star} 6^{\prime \prime \prime}$ were much smaller (Figs 44, 48). The posterior intercalary plate (1p) was small and elongated, located adjacent to plate $\mathrm{Sp}$ (Fig. 44). The antapical plate $\left(1^{\prime \prime \prime \prime}\right)$ was six-sided and located in the middle of the hypotheca (Fig. 48). Cysts were not observed in cultures.

\section{Molecular analysis and phylogeny}

When SSU rDNA sequences were compared, Pentaplacodinium usupianum strains DSB01, GgSm01, GgSm07, GgSm10 and GgSm11 showed 0-1 base pair divergence (99.94\% similarity) 

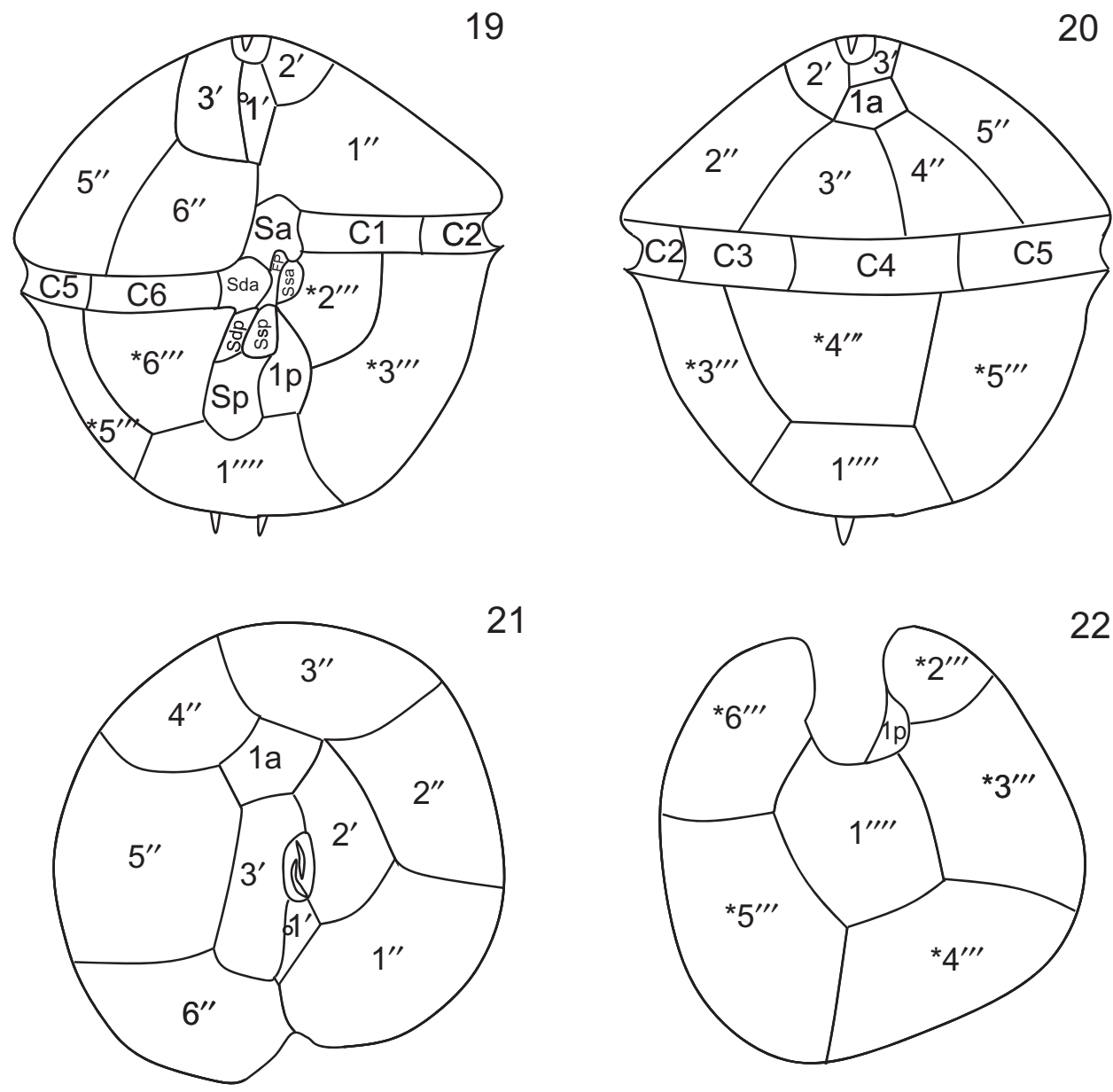

Figs 19-22. Schematic drawings of thecal plate patterns of Ceratocorys malayensis.

Fig. 19. Ventral view.

Fig. 20. Dorsal view.

Fig. 21. Apical view.

Fig. 22. Antapical view.

but differed from Pentaplacodinium saltonense (MG646323) in six positions (99.65\% similarity). Protoceratium cf. reticulatum HWYD1 differed from Protoceratium reticulatum (AY421790) at 12 positions ( $99.30 \%$ similarity). Ceratocorys malayensis strain A10-49-A55 differed from Ceratocorys horrida (DQ388456) and Ceratocorys sp. (LC054924) in 1 and 4 positions (99.77\% and 99.94\% similarity), respectively.

Pairwise comparison of LSU rDNA sequences revealed that Pentaplacodinium usupianum strains DSB01, DSB02, GgSm01, GgSm03, GgSm07, GgSm10, and GgSm11 differed in 0-2 positions (99.64\% similarity), but up to 25 divergent positions were observed when compared to Pentaplacodinium saltonense (FJ155820, 95.57\% similarity). Protoceratium cf. reticulatum HWYD1 differed from Protoceratium reticulatum (FJ155821) in 13 positions $(97.70 \%$ similarity). Ceratocorys malayensis strains A10-49-A55, A10-49-A56, A10-49-A61, PrTT01, PrTT02 and PrTT03 differed from each other in $0-2$ positions (99.64\% similarity) and differed from Ceratocorys horrida in 2-3 positions (99.47-99.64\% similarity).

When ITS rDNA sequences were compared, Pentaplacodinium usupianum strains DSB01, DSB02 GgSm01, GgSm03, GgSm07, GgSm10, and GgSm11 differed from each other in $0-4$ positions $(99.28 \%$ similarity $)$, and from
Pentaplacodinium saltonense (EU532485) in 123 positions (77.83\% similarity). Protoceratium cf. reticulatum HWYD1 differed from Protoceratium reticulatum (AB727654) in 105 positions ( $79.65 \%$ similarity). Ceratocorys malayensis strains A10-49-A55, A10-49-A56, A10-49-A61, PrTT01, PrTT02 and PrTT03 shared identical sequences and differed from Ceratocorys horrida in 33 positions ( $94.10 \%$ similarity). Genetic distances among Pentaplacodinium, Ceratocorys and Protoceratium species were greater than 0.18 , but between Ceratocorys malayensis and C. horrida was only 0.06 (Table 2).

The maximum likelihood (ML) and Bayesian inference (BI) topologies based on the SSU rDNA sequences yielded similar phylogenetic trees. The ML tree is illustrated in Fig. 51. Protoceratiaceae formed a monophyletic clade with maximal support (100 BS/1.0 BPP) and comprised Ceratocorys, Protoceratium and Pentaplacodinium with an early divergence of Ceratocorys. Gonyaulaceceae was monophyletic with strong ML support (100) but low BI posterior probability $(<0.7)$ comprising Gonyaulax and Lingulodinium. Ceratocorys malayensis grouped with C. horrida and Ceratocorys sp. with maximal support. Protoceratium cf. reticulatum was closest to Protoceratium reticulatum with strong support (100 BS/0.94 BPP). Pentaplacodinium usupianum and $P$. saltonense formed a clade with strong support 

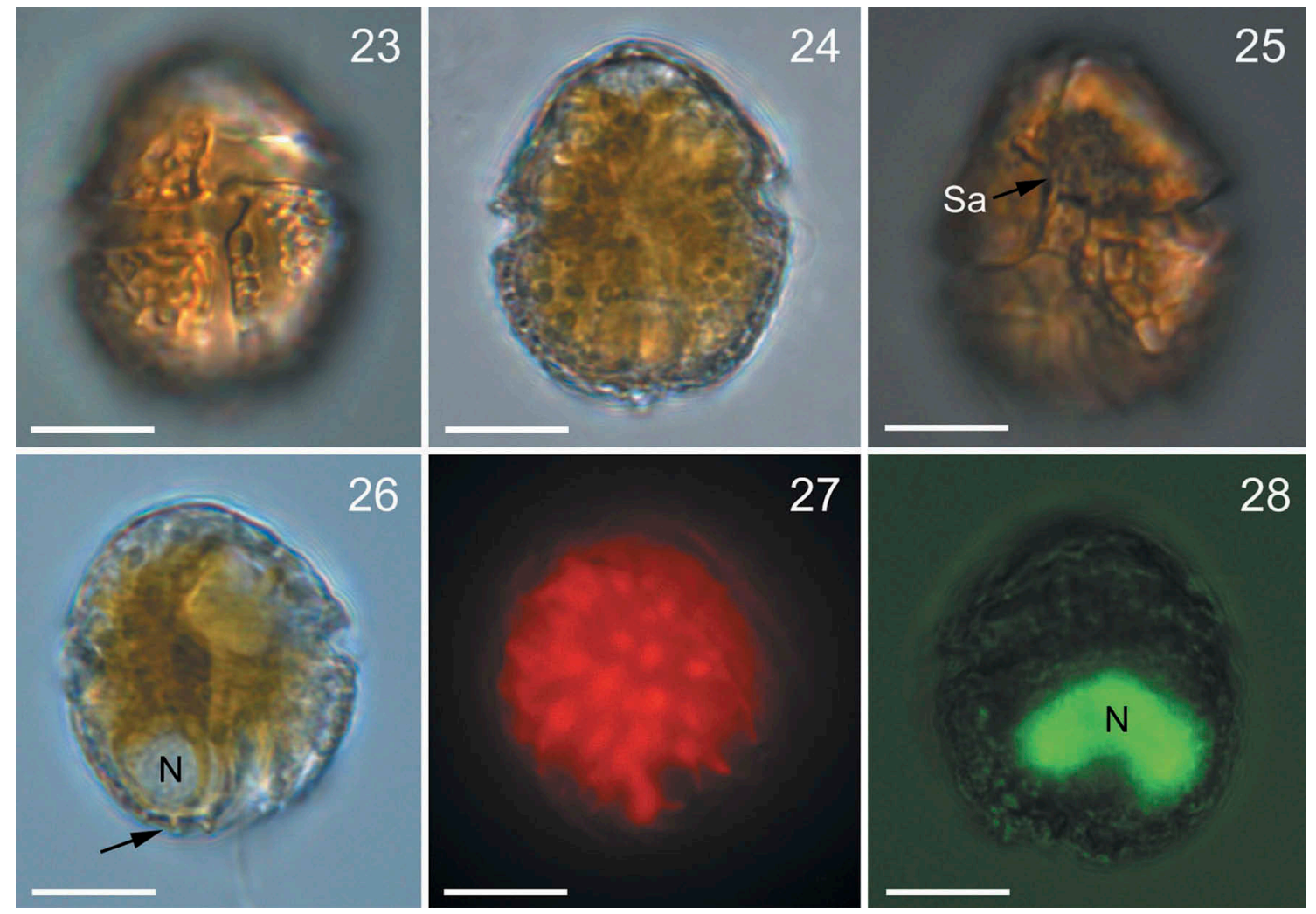

Figs 23-28. Light micrographs of live cells of Pentaplacodinium usupianum strain DBS02. Scale bar $=10 \mu \mathrm{m}$.

Fig. 23. Ventral view showing cingulum displacement and posterior widening of sulcus.

Fig. 24. Dorsal view showing a conical epitheca and rounded hypotheca.

Fig. 25. Ventral view, showing anterior sulcal plate $(\mathrm{Sa})$ intruding the epitheca.

Fig. 26. Dorsal view, with nucleus $(\mathrm{N})$ and several spines at antapex (arrow).

Fig. 27. Dorsal view, with numerous autofluorescent chloroplasts.

Fig. 28. SYBR Green-stained cell, with U-shaped nucleus (N).

(100 BS/0.88 BPP) which was a sister clade of Protoceratium reticulatum with strong support (100 BS/0.99 BPP).

$\mathrm{ML}$ and BI analyses based on partial LSU rDNA sequences yielded identical phylogenetic trees. The ML tree is illustrated in Fig. 52. Ceratocorys malayensis was well-resolved (100 BS/0.72 BPP) and grouped with C. horrida, C. gourretii and C. armata with maximal support. Pentaplacodinium usupianum was wellresolved (100 BS/0.96 BPP) and formed a sister clade to Pentaplacodinium saltonense with high ML bootstrap support (100) but low BI posterior probability $(<0.7)$. Protoceratium $\mathrm{cf}$. reticulatum was closest to Protoceratium reticulatum with strong support (100 BS/0.97 BPP).

ML and BI analysis based on ITS rDNA sequences yielded identical phylogenetic trees too. The ML tree is illustrated in Fig. 53. Ceratocorys malayensis grouped with $C$. horrida with maximal support, which diverged early in the tree. Pentaplacodinium usupianum was well-resolved (100 BS/0.98 BPP) and formed a sister clade to $P$. saltonense with maximal support. They formed a sister clade to Protoceratium cf. reticulatum and $P$. reticulatum with strong support (100 BS/ $0.85 \mathrm{BPP})$.

\section{Analysis of yessotoxin}

None of the examined strains of Ceratocorys malayensis, Pentaplacodinium usupianum and Protoceratium cf. reticulatum produced detectable yessotoxins (Table 1). Limits of detection for YTX ranged between 0.09 and $2.8 \mathrm{fg}$ cell $^{-1}$ depending on available biomass.

\section{DISCUSSION}

\section{Morphology}

A characteristic feature of the genus Ceratocorys is the broad contact of the sixth precingular homolog $\left({ }^{*} 6^{\prime \prime}\right)$ with the first precingular plate $\left(1^{\prime \prime}\right)$, thus leading to an episert type I topology where plate 1' does not contact Sa (Paez-Reyes \& Head 2013). Ceratocorys is also characterised by an angular body and a much larger hypotheca than epitheca (CarbonellMoore 1996; Graham 1942). The strain A10-49-A55 (Ceratocorys malayensis) matches the description of Ceratocorys except that it possesses six precingular plates instead of five. It would appear that a new genus is needed to incorporate our strains; however, the fourth precingular plate in Ceratocorys has been considered homologous to the fourth and fifth precingular plates in other gonyaulacoids (Carbonell-Moore 1996); therefore, our strains justify classification in Ceratocorys if this variability is allowed through emendation of the genus.

Our strain A10-49-A55 is morphologically similar to Ceratocorys anacantha in terms of a ventral pore of plate 1', 



Figs 29-35. Scanning electron micrographs of Pentaplacodinium usupianum strain DBS02.

Fig. 29. Ventral view showing first apical plate $\left(1^{\prime}\right)$, anterior sulcal plate $(\mathrm{Sa})$, first and sixth precingular plates $\left(1^{\prime \prime}, 6^{\prime \prime}\right)$, second and sixth postcingular plates $\left({ }^{*} 2^{\prime \prime \prime}\right.$, $\left.{ }^{*} 6^{\prime \prime \prime}\right)$, posterior intercalary plate (1p), first antapical plate $\left(1^{\prime \prime \prime \prime}\right)$ and posterior sulcal plate $(\mathrm{Sp})$. Scale bar $=10 \mu \mathrm{m}$.

Fig. 30. Apical view showing three apical plates $\left(1^{\prime}-3^{\prime}\right)$, one anterior intercalary (1a) plate and six precingular plates $\left(1^{\prime \prime}-6^{\prime \prime}\right)$. Scale bar $=10 \mu \mathrm{m}$

Fig. 31. Antapical view showing five postcingular plates $\left({ }^{*} 2^{\prime \prime \prime}-{ }^{*} 6^{\prime \prime \prime}\right)$, posterior intercalary plate $(1 \mathrm{p})$ and antapical plate $\left(1^{\prime \prime \prime \prime}\right)$. Scale bar $=10 \mu \mathrm{m}$.

Fig. 32. Cingulum with six plates (C1-C6). Scale bar $=10 \mu \mathrm{m}$.

Figs 33,34 . Detail of oval to elliptical pore plate with $\lambda$-shaped cover plate and perforated by pores. Scale bar $=2 \mu \mathrm{m}$.

Fig. 35. Sulcus showing anterior sulcal plate (Sa), anterior left sulcal plate (Ssa), anterior right sulcal plate (Sda), posterior left sulcal plate (Ssp), and posterior right sulcal plate (Sdp). Scale bar $=2 \mu \mathrm{m}$.

and the dorsal position of plate $3^{\prime \prime}$, but it differs in the absence of spines in the hypotheca of $C$. anacantha and the number of precingular plates (six versus five; Carbonell-Moore 1996). The antapical spine length can vary in Ceratocorys, e.g., C. horrida can reduce spine size, or even lose them completely, due to hydrodynamic forces (Zirbel et al. 2000). Strain A10-49-A55 can be differentiated from other Ceratocorys species based on the number of precingular plates, as well as the relative size and configuration of plate $3^{\prime \prime}$. Plate 3 " of strain A10-49-A55 is symmetrical and its central median line nearly coincides with the epitheca. In contrast, plate $3 "$ of C. anacantha, C. grahamii, C. armata, C. aultii, C. bipes, C. gourretii, C. reticulata, and C. skogsbergii is either not symmetrical, or not dorsal (CarbonellMoore 1996; Graham 1942). Therefore, strain A10-49-A55 was described as a new species.

Pentaplacodinium differs from Ceratocorys in that it has a first apical plate of an insert type which touches the Sa plate. As a consequence, there is no contact between plates $1^{\prime \prime}$ and $6 "$ in Pentaplacodinium, whereas in Ceratocorys contact is broad (Mertens et al. 2018a). Our strain DBS02 (Pentaplacodinium usupianum) displays an insert type of plate $1^{\prime}$, but occasionally plate $1^{\prime}$ does not contact plate Sa, i.e., showing episert type I (Figs S5, S6), as also reported in P. saltonense (Salgado et al. 2018) and Protoceratium cf. reticulatum strain HWYD1 (Figs 44, 45). Presence of both insert type and episert type within a single strain is possibly due to culture artefacts, thus field samples are needed for verification. Our strain DBS02 thus fits the definition of Pentaplacodinium except that it had six precingular plates instead of five, and the torsion was more neutral. Regardless, a new genus is unnecessary since the third precingular plate in Pentaplacodinium is homologous to the third and fourth precingular plates in other gonyaulacoids (Mertens et al. 2018b). Thus, our strains justify classification in Pentaplacodinium, pending its emendation. To date, only Pentaplacodinium saltonense has been described for this genus. The strain studied here differed from $P$. saltonense in the absence of a ventral pore on plate $1^{\prime}$ and the number of precingular plates (Mertens et al. 2018b). Therefore, it was described as a new species.

Our strain HWYD1 is morphologically similar to Protoceratium reticulatum, except that it lacks a ventral pore on plate $1^{\prime}$ and is much smaller $(26 \mu \mathrm{m}$ long versus $40 \mu \mathrm{m}$ long; Hansen et al. 1997). Another morphological feature that differentiates both is that in $P$. reticulatum the contact between plates $1^{\prime}$ and $\mathrm{Sa}$ is always wide (plates $6^{\prime \prime}$ and $1^{\prime \prime}$ are well separated), whereas in $P$. cf. reticulatum strain HWYD1 the contact is slight (Fig. 45) or absent (Fig. 44). Gonyaulax 

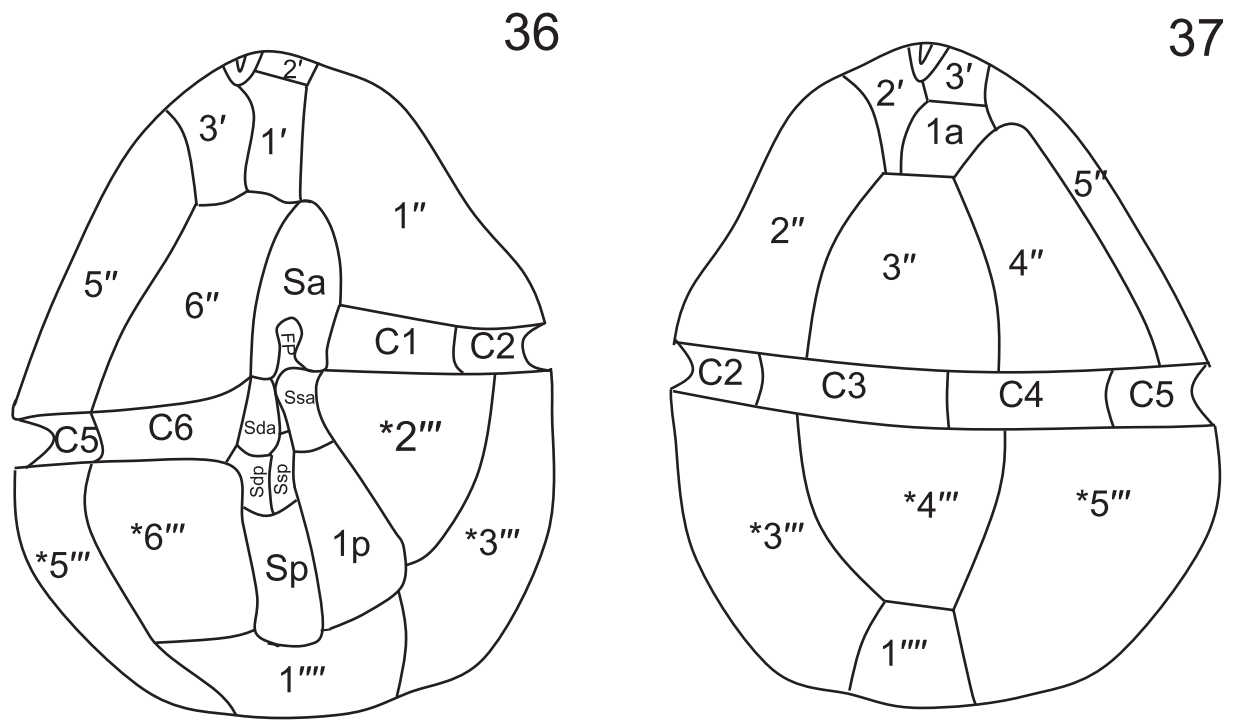

38
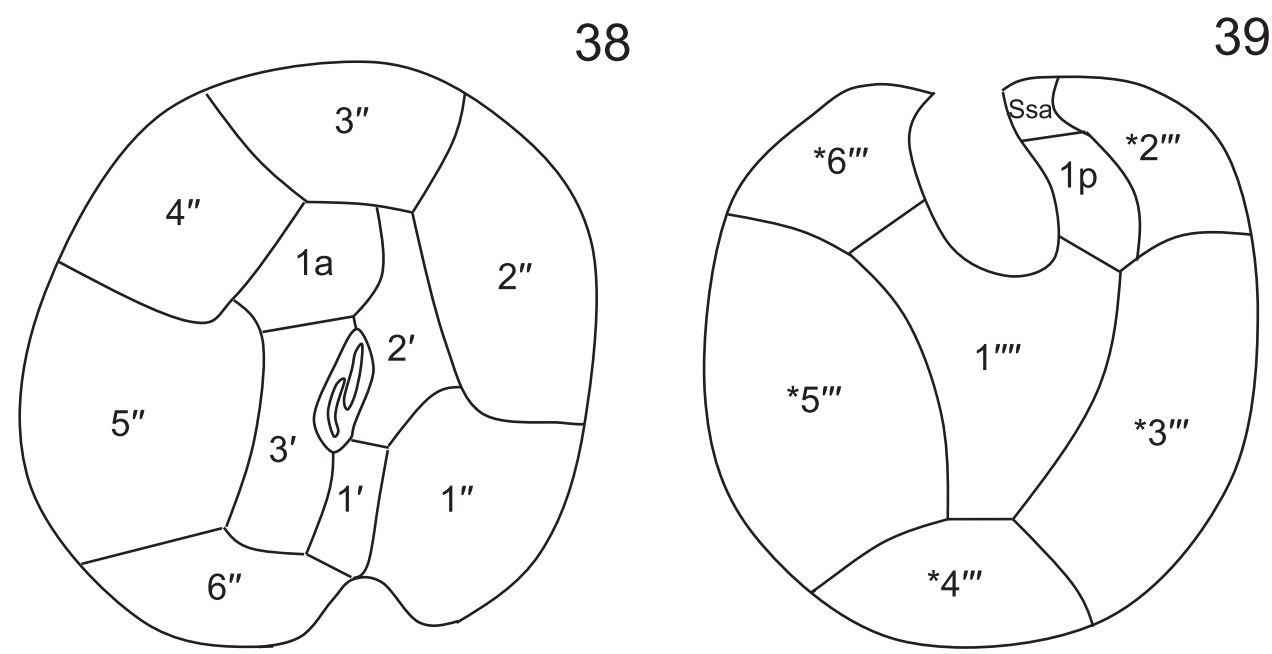

Figs 36-39. Schematic drawings of thecal plate patterns of Pentaplacodinium usupianum.

Fig. 36. Ventral view.

Fig. 37. Dorsal view.

Fig. 38. Apical view.

Fig. 39. Antapical view.

grindleyi also lacks a ventral pore, but it was regarded as a junior synonym of Protoceratium reticulatum (Hansen et al. 1997). From the type locality of G. grindleyi, cells of $P$. reticulatum were confirmed through ITS rDNA sequence comparison (Mertens et al. 2018b). It is possible that $G$. grindleyi is not a synonym of $P$. reticulatum but that both are present at Elands Bay, Cape Province, South Africa. However, this will not be clarified until more specimens from Cape Province are examined. Protoceratium reticulatum from the Mexican Pacific also lacks a ventral pore and toxin production was not detected either (Hernandez-Becerril et al. 2010). However, strain PRPV-1 of P. reticulatum from the Mexican Pacific (Gulf of California) was grouped with other strains of the species from various geographic locations in the molecular phylogenetic tree of Salgado et al. (2018). In the same area of the Mexican Pacific, Morquecho et al. (2009) reported Protoceratium globosum characterised by a large ventral pore, but it was considered to be a synonym of Pentaplacodinium saltonense (Mertens et al. 2018b).
Protoceratium splendens from the Kara Sea is possibly a junior synonym of $P$. reticulatum as suggested by Gómez (2012). Whether or not P. splendens has a ventral pore was not clarified (Meunier 1910). Protoceratium encompass many other species, e.g. Protoceratium aculeatum, Protoceratium areolatum and Protoceratium spinulosum, but some descriptions do not even have illustrations, e.g., P. cancellorum, $P$. pellucidissimum, $P$. pepo, $P$. globosum and $P$. promissum (Kofoid \& Michener 1911). More sequences of Protoceratium species are necessary to confirm the validity of these species. An unidentified Protoceratium species was reported from the southwestern Atlantic Ocean characterised by spines throughout the cell body (Balech 1988), and its correct identity remains to be determined.

\section{Molecular phylogeny and genetic differentiation}

Our results support the classification of strains HWYD1, A1049-A55, and DBS02 within Protoceratium, Ceratocorys and 

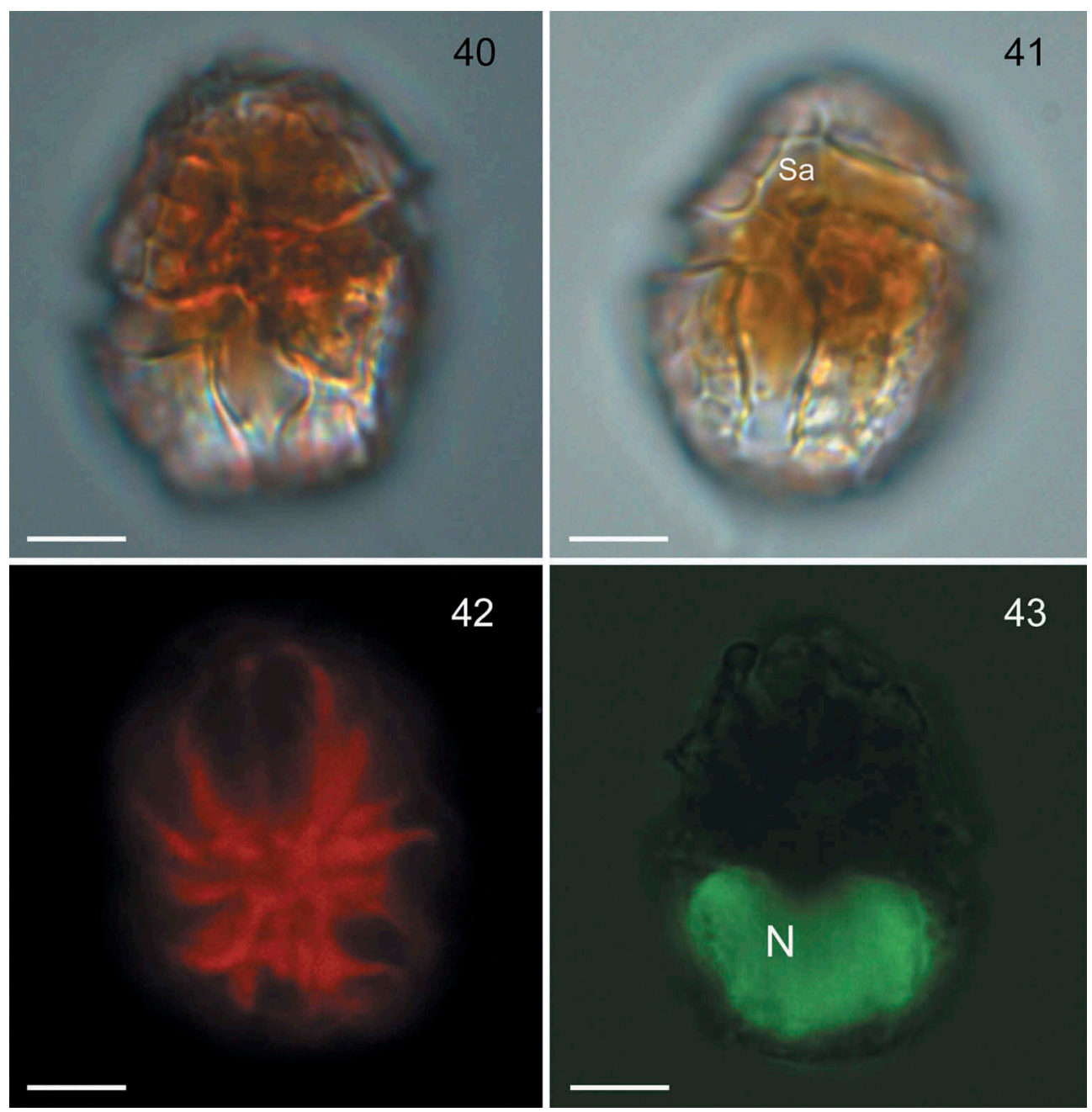

Figs 40-43. Light micrographs of live cells of Protoceratium cf. reticulatum strain HWYD1. Scale bars: $5 \mu \mathrm{m}$.

Fig. 40. Ventral view showing cingulum displacement and posterior widening of sulcus.

Fig. 41. Ventral view showing anterior sulcal plate $(\mathrm{Sa})$ intruding the epitheca.

Fig. 42. Dorsal view, showing autofluorescent chloroplast network.

Fig. 43. A SYBR Green-stained cell, showing curved nucleus (N).

Pentaplacodinium respectively, with the latter two new to science. Genetic distance based on ITS rDNA sequences is greater than 0.3 between species of Pentaplacodinium, much higher than the threshold value (0.04) to differentiate dinoflagellates at inter-specific level (Litaker et al. 2007). In contrast, the ITS rDNA sequences based genetic distances between Ceratocorys malayensis and C. horrida is only 0.06, and C. horrida even shares identical LSU rDNA sequences with C. gourretii, suggesting that speciation in Ceratocorys might have occurred quite recently. The ITS rDNA sequencebased genetic distances between strain HWYD1 and Protoceratium reticulatum was 0.18 , suggesting that this strain represents a different species. However, strain HWYD1 shares similar morphology with $P$. reticulatum except that it lacks a ventral pore, and the contact between plates $1^{\prime \prime}$ and Sa is much slighter. A ventral pore has been regarded as the key feature to differentiate Azadinium species (Luo et al. 2017), but it can be either present or absent in some Alexandrium species (e.g. John et al. 2014). Strain HWYD1 must have a cyst stage as it originated from direct incubation of sediments. The cyst-theca relationship, however, is not available at the moment although we did observe cysts of $P$. reticulatum from the same sample from Hawaii $(\mathrm{Gu}$, personal observations). Therefore, strain HWYD1 is not described as a new species at the moment, especially because only one Protoceratium species has sequences available.

Our molecular phylogeny based on SSU rDNA sequences supports the close relationship between the gonyaulacoid families Protoceratiaceae and Gonyaulaceceae, as previously reported with concatenated data from ribosomal DNA, mitochondrial, and nuclear protein genes (Orr et al. 2012). These molecular results are consistent with the fact that both families have been included within the suborder Gonyaulacineae based on morphological evidence (Fensome et al. 1993). Previously, the key difference between Gonyaulacaceae and Ceratocorythaceae (here considered a junior synonym of Protoceratiaceae) was the number of precingular plates (six versus five; Fensome et al. 1993), but we show that Ceratocorys incorporates species with both five and six precingular plates. The number of anterior intercalary plates appears promising to separate Protoceratiaceae from Gonyaulacaceae. 

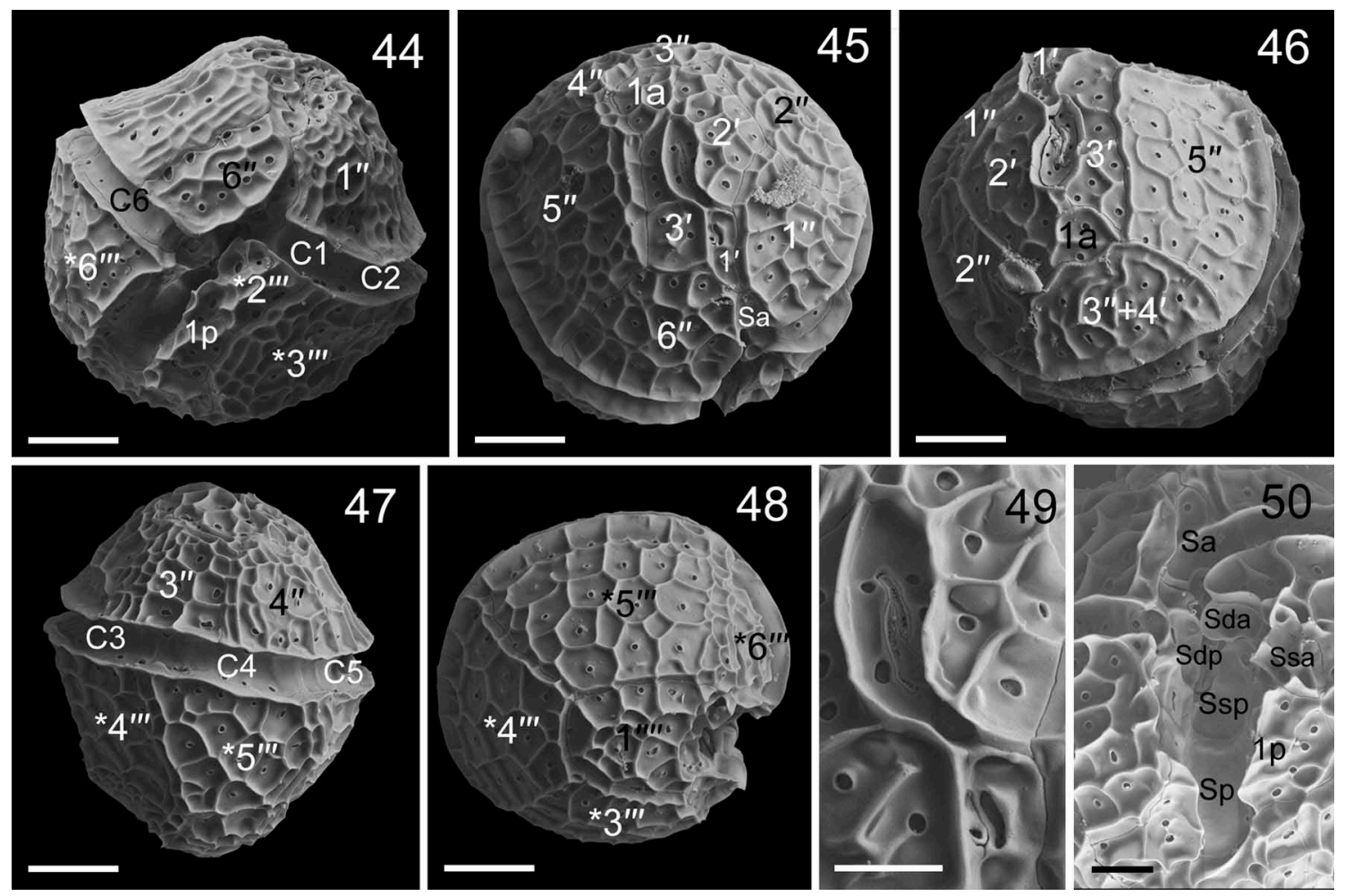

Figs 44-50. Scanning electron micrographs of Protoceratium cf. reticulatum strain HWYD1.

Fig. 44. Ventral view showing first and sixth precingular plates $\left(1^{\prime \prime}, 6^{\prime \prime}\right)$, second, third and sixth postcingular plates $\left({ }^{*} 2^{\prime \prime \prime},{ }^{*} 3^{\prime \prime \prime}\right.$ and $\left.{ }^{*} 6^{\prime \prime \prime}\right)$, posterior intercalary plate (1p) and three cingular plates (C1, C2 and C6). Scale bar $=5 \mu \mathrm{m}$.

Fig. 45. Apical view showing three apical plates $\left(1^{\prime}-3^{\prime}\right)$, one anterior intercalary (1a) plate and six precingular plates $\left(1^{\prime \prime}-6^{\prime \prime}\right)$. Scale bar $=5 \mu \mathrm{m}$.

Fig. 46. Apical view showing three apical plates $\left(1^{\prime}-3^{\prime}\right)$, one anterior intercalary (1a) plate and five precingular plates $\left(1^{\prime \prime}-5^{\prime \prime}\right)$. Scale bar $=5 \mu \mathrm{m}$.

Fig. 47. Dorsal view showing three cingular plates $\left(C 3, C 4\right.$ and $(5)$, two precingular plates $\left(3^{\prime \prime}, 4^{\prime \prime}\right)$ and two postcingular plates $\left({ }^{*} 4^{\prime \prime \prime},{ }^{*} 5^{\prime \prime \prime}\right)$ with evident dextral torsion. Scale bar $=5 \mu \mathrm{m}$.

Fig. 48. Antapical view showing four postcingular plates $\left({ }^{*} 3^{\prime \prime \prime}-{ }^{*} 6^{\prime \prime \prime}\right)$ and antapical plate $\left(1^{\prime \prime \prime \prime}\right)$. Scale bar $=5 \mu \mathrm{m}$.

Fig. 49. Detail of the sigmoidal pore plate with a $\lambda$-shaped cover plate and perforated by pores. Scale bar $=2 \mu \mathrm{m}$.

Fig. 50. Sulcus showing anterior sulcal plate (Sa), anterior left sulcal plate (Ssa), anterior right sulcal plate (Sda), posterior left sulcal plate (Ssp), posterior right sulcal plate (Sdp), and posterior sulcal plate (Sp). Scale bar $=2 \mu \mathrm{m}$.

Table 2. Pairwise genetic distances based on ITS rDNA sequences for Protoceratium, Pentaplacodinium and Ceratocorys species.

\begin{tabular}{|c|c|c|c|c|c|c|}
\hline Species (GenBank numbers) & AB727654 & MG646295 & DBS02 & EU532485 & A10-49-A55 & EU927577 \\
\hline Protoceratium reticulatum (AB727654) & - & & & & & \\
\hline Protoceratium cf. reticulatum (MG646295) & 0.18 & - & & & & \\
\hline Pentaplacodinium saltonense (EU532485) & 0.35 & 0.35 & 0.19 & - & & \\
\hline Ceratocorys malayensis (MN137896) & 0.37 & 0.34 & 0.36 & 0.35 & - & \\
\hline Ceratocorys horrida (EU927577) & 0.37 & 0.35 & 0.36 & 0.37 & 0.06 & - \\
\hline
\end{tabular}

Protoceratiaceae are characterised by having one anterior intercalary plate, whereas in Gonyaulacaceae, the anterior intercalary plate may be absent, but when present, two or more anterior intercalary plates occur (Dodge 1989). The pore plate can vary from oval to elliptic in Pentaplacodinium usupianum (Figs 33, 34) and Protoceratium reticulatum (Sala-Pérez et al. 2016), but a $\lambda$ shaped pore is always present in Pentaplacodinium, Ceratocorys and Protoceratium (Sala-Pérez et al. 2016, present study). In contrast, species of Gonyaulax show a lanceolate pore (Dodge 1989; Escalera et al. 2018). As a consequence, Protoceratium and Pentaplacodinium are here classified within the Protoceratiaceae.

Ventral organisation and dextral torsion were also used to define the family Protoceratiaceae, e.g. an L-type sulcus and strong dextral torsion. However, our new species of Ceratocorys has sinistral torsion. Torsion can even be variable within one genus or species. Protoceratium strain HWYD1 had sexiform gonyaulacoid tabulation with an L-type ventral organisation and dextral torsion. Pronounced dextral torsion was also reported for specimens from the North Sea (the type area for Protoceratium reticulatum; Röder et al. 2012) and from the Pacific Ocean off Chile (Álvarez et al. 2011). However, neutral torsion occurred in samples from Plymouth, UK (Lebour 1925, pl. 12, fig. 7), and specimens from the Mexican Pacific appear slightly sinistral to neutrally contorted (Hernandez-Becerril et al. 2010, figs 23 and 24, respectively). 


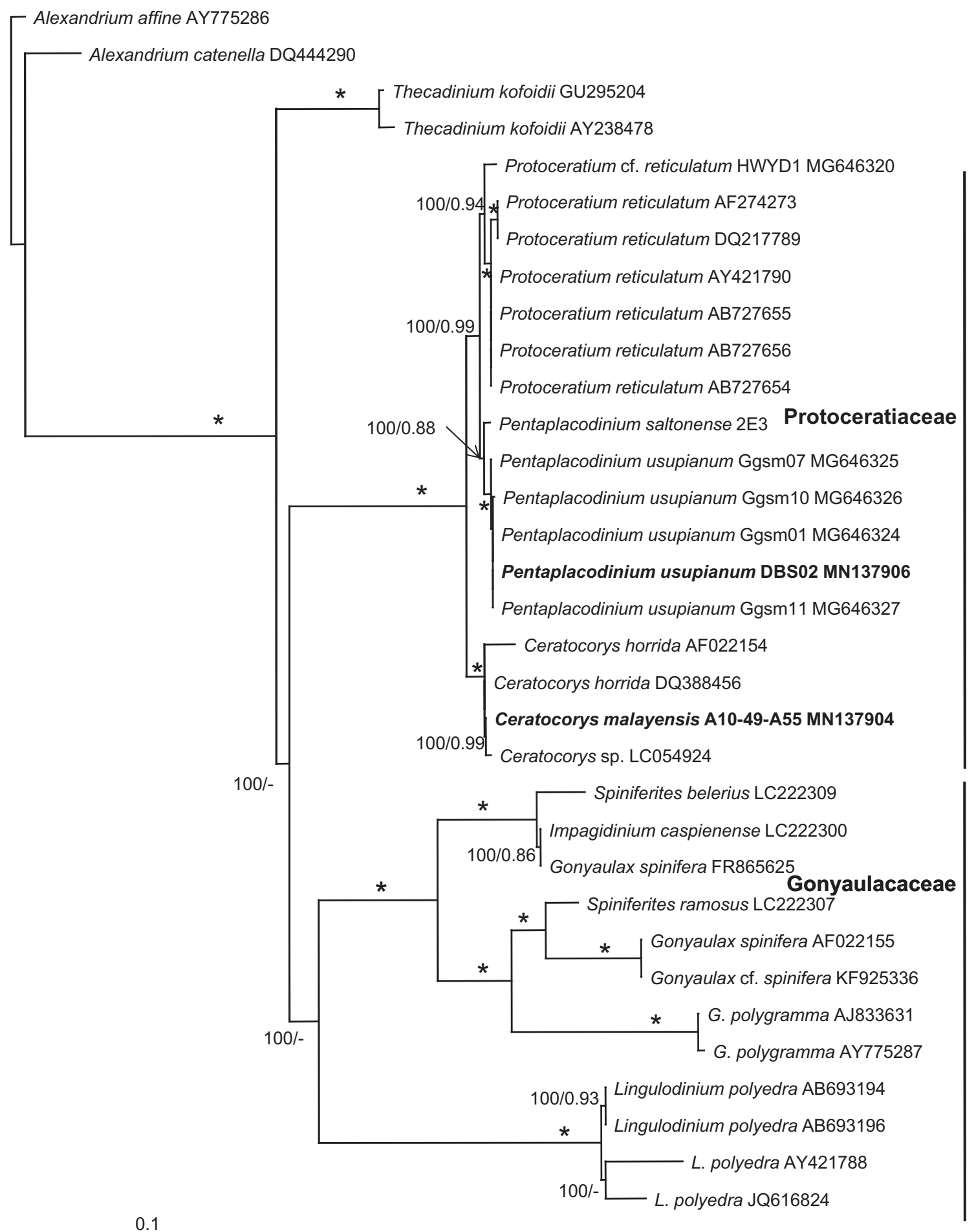

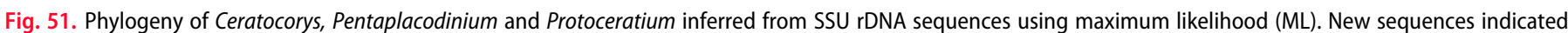

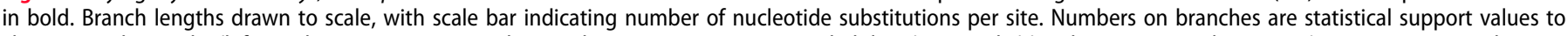

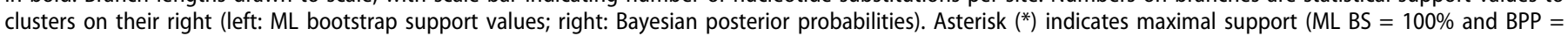
$1.00)$.

The close morphological similarity between Pentaplacodinium and Protoceratium is also reflected in our SSU, ITS rDNA sequence-based phylogeny (Figs 51, 53) and V4 region of LSU rDNA sequences-based phylogeny (Mertens et al. 2018b). Both share a first apical plate of an insert type, and the number of precingular plates can be the same too. Unlike these two genera, Ceratocorys shows an episert type in the first apical plate. The early divergence of Ceratocorys suggests that the insert type is a derived character. 


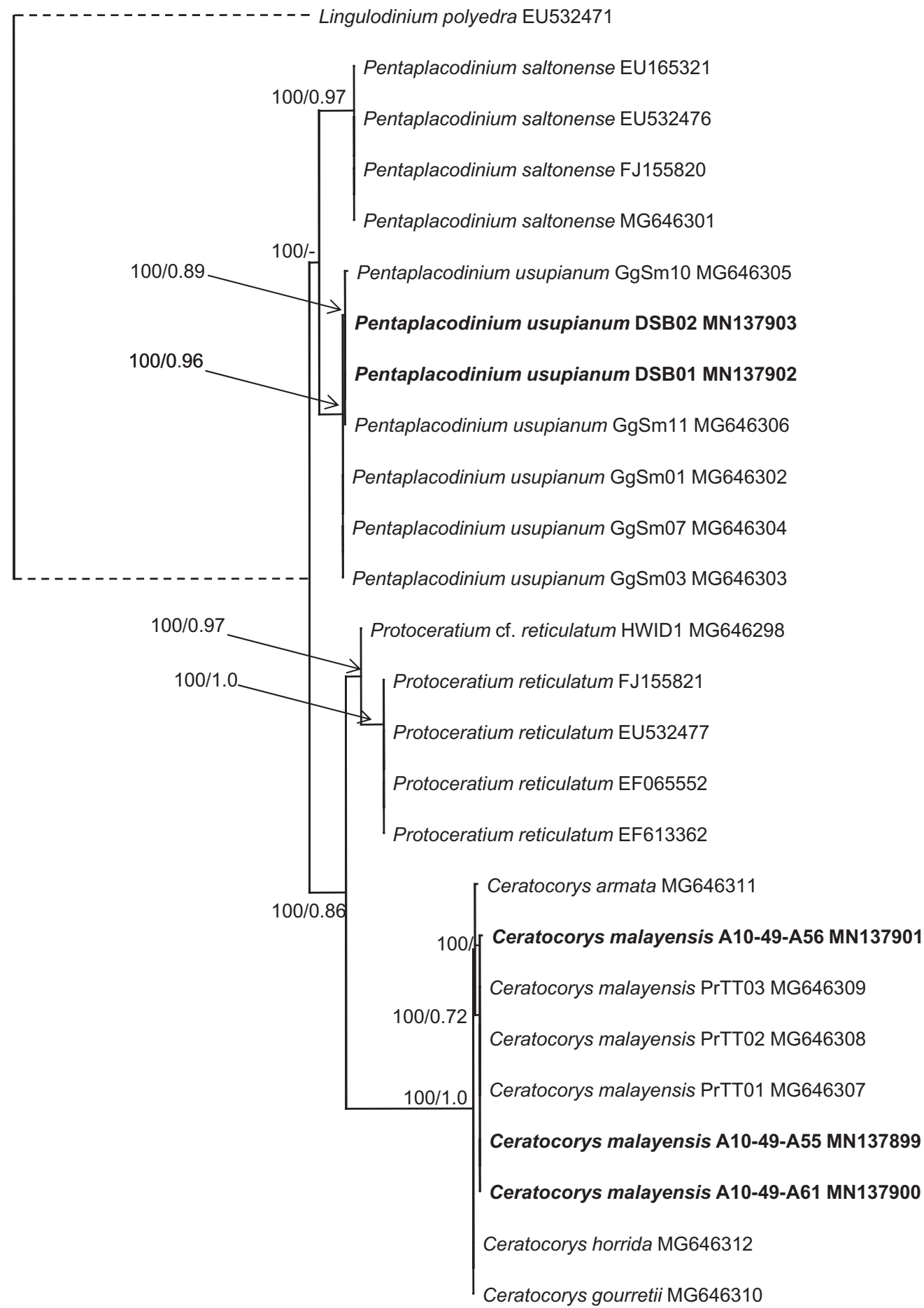

Fig. 52. Phylogeny of Ceratocorys, Pentaplacodinium and Protoceratium inferred from partial LSU rDNA sequences using maximum likelihood (ML). New sequences indicated in bold. Branch lengths drawn to scale, with scale bar indicating number of nucleotide substitutions per site. Numbers on branches are statistical support values to clusters on their right (left: ML bootstrap support values; right: Bayesian posterior probabilities). Dashed lines indicate half length.

\section{Protoceratiaceae Lindemann 1928 emend. H.Gu \& Mertens}

Gonyaulacineans with five or six precingular plates and a midventral, L-type sulcus; only one anterior intercalary plate present.
Gonyaulacaceae Lindemann 1928 emend. H.Gu \& Mertens

Gonyaulacineans with sulcus more or less midventral and straight, oblique from upper right to lower left, or sigmoidal. Antapical outline more or less symmetrical and strong 


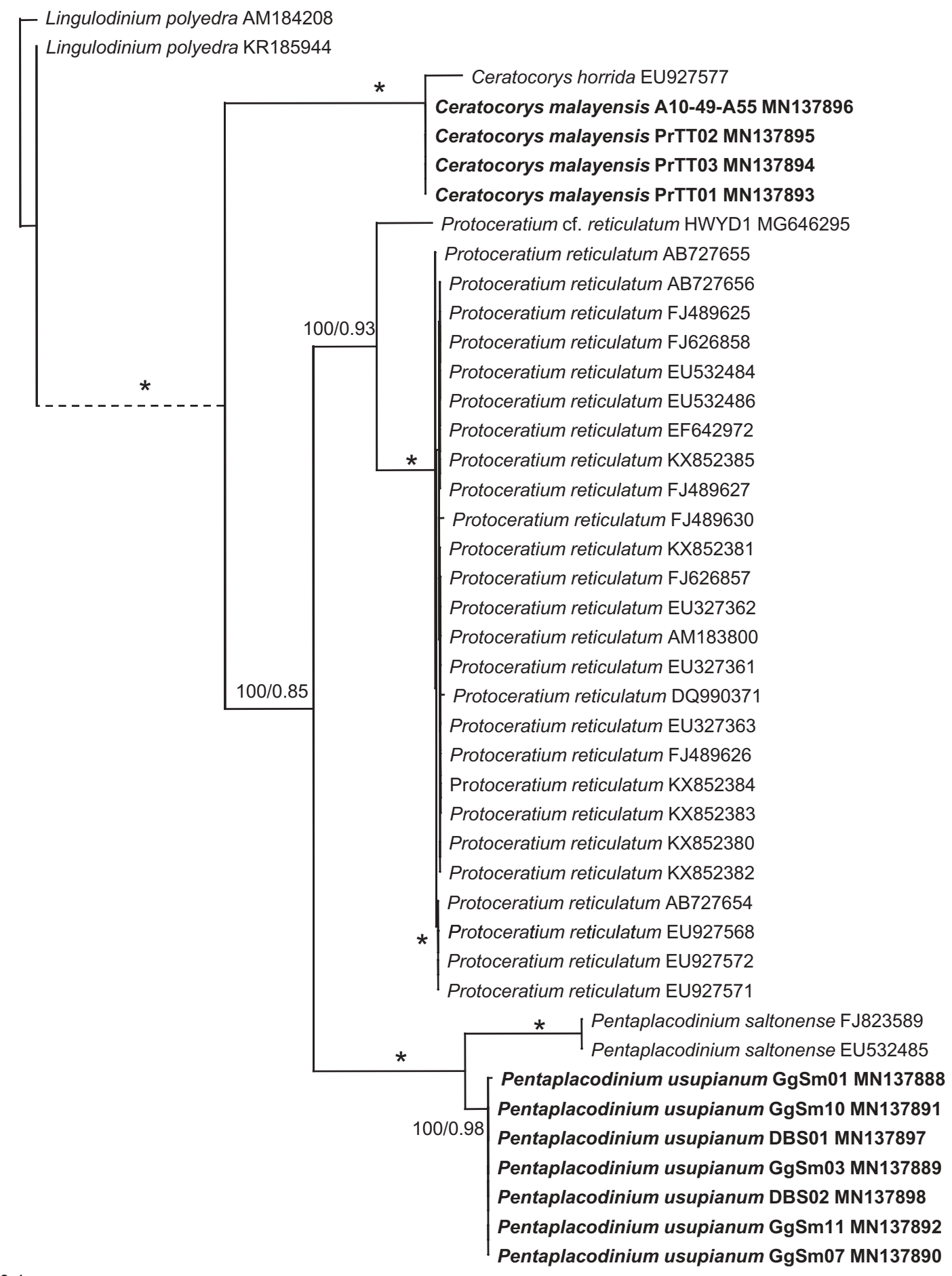

$\underline{0.1}$

Fig. 53. Phylogeny of Ceratocorys, Pentaplacodinium and Protoceratium inferred from ITS rDNA sequences using maximum likelihood (ML). New sequences indicated in bold. Branch lengths drawn to scale, with scale bar indicating number of nucleotide substitutions per site. Numbers on branches are statistical support values to clusters on their right (left: ML bootstrap support values; right: Bayesian posterior probabilities). Asterisk $\left(^{*}\right)$ indicates maximal support (ML BS $=100 \%$ and BPP $=$ 1.00). Dashed line indicates half length.

dorsoventral compression lacking. Six precingular plates and, when present, two or more anterior intercalary plates.

\section{Ceratocorys F.Stein emend. H.Gu \& Mertens}

A gonyaulacinean genus with polygonal theca bearing reticulated plates, with tabulation Po, Pt, 3', 1a, 5-6", 6C, 6-7S, 5"', 1p, 1'"' and oval pore plate; plate $1^{\prime}$ of episert type I. Resting cysts unknown.
Pentaplacodinium Mertens, Carbonell-Moore, Pospelova \& Head emend. H.Gu \& Mertens

A gonyaulacinean genus with roundish theca bearing reticulated plates and tabulation Po, Pt, 3', 1a, 5-6", 6C, 6-7S, 5"', $1 \mathrm{p}, 1^{\prime \prime \prime \prime}$, and an oval to elliptical pore plate. Plate $1^{\prime}$ of insert type with minimal contact between plates $1^{\prime \prime}$ and $6^{\prime \prime}$. Operculodinium-type cysts described. 


\section{Protoceratium Bergh emend. H.Gu \& Mertens}

Small, oval to broadly biconical cell, bearing reticulated plates, with plate formula Po, Pt, 3', 1a, 6", 6C, 6S, 5"', 1p, 1"'"; pore plate round with a $\lambda$-shaped cover plate; plate $1^{\prime}$ of insert type. Operculodinium-type cysts described.

The classification of Pentaplacodinium and Protoceratium within Protoceratiaceae is supported by the morphological similarity to Ceratocorys in possessing only one anterior intercalary plate and possibly a $\lambda$-shaped pore too. The latter feature has not been confirmed in other Ceratocorys species. The configuration of the anterior sulcal plate appears to be conservative in Ceratocorys but not in Pentaplacodinium and Protoceratium since both insert type and episert type can be present in the latter two genera. Future research on the cyst-theca relationships of Protoceratium and related species, and more sequences of gonyaulacoid species will provide futher insight into the relationship between Protoceratiaceae and Gonyaulacaceae.

\section{ACKNOWLEDGEMENTS}

We thank two anonymous reviewers for constructive suggestions that greatly improved the manuscript.

\section{FUNDING}

This work was supported by the National Key Research and Development Program of China (2016YFE0202100), the National Natural Science Foundation of China (41676117) and China-ASEAN Maritime Cooperation Fund. It was partially funded by HelmholtzGemeinschaft Deutscher Forschungszentren through the research program "Polar regions And Coasts in the changing Earth System" (PACES) of the Alfred Wegener Institut-Helmholtz Zentrum für Polar- und Meeresforschung, and International Collaborative Fund [CF001-2018] from Malaysia Ministry of Energy, Science, Technology, Environment and Climate Change (MESTECC), and Ministry of Education HICoE and RU fund [IOES-2014C; TU001A-2018].

\section{ORCID}

Haifeng Gu (D) http://orcid.org/0000-0002-2350-9171

\section{REFERENCES}

Adachi M., Sako Y. \& Ishida Y. 1996. Analysis of Alexandrium (Dinophyceae) species using sequences of the $5.8 \mathrm{~S}$ ribosomal DNA and internal transcribed spacer regions. Journal of Phycology 32: 424-432. DOI: 10.1111/j.0022-3646.1996.00424.x.

Álvarez G., Uribe E., Díaz R., Braun M., Mariño C. \& Blanco J. 2011. Bloom of the yessotoxin producing dinoflagellate Protoceratium reticulatum (Dinophyceae) in northern Chile. Journal of Sea Research 65: 427-434. DOI: 10.1016/j.seares.2011.03.008.

Balech E. 1980. On the thecal morphology of dinoflagellates with special emphasis on circular and sulcal plates. Anales Del Centro De Ciencias Del Mar Y Limnologia, Universidad Nacional Autonomia De Mexico 7: 57-68.

Balech E. 1988. Los dinoflagelados del Atlántico sudoccidental. Publicaciones Especiales. Instituto Español De Oceanografía 1: 1-310.

Bergh R.S. 1881. Der Organismus der Cilioflagellaten. Eine phylogenetische Studie. Morphologisches Jahrbuch 7: 177-288.

Boc A., Diallo A.B. \& Makarenkov V. 2012. T-REX: a web server for inferring, validating and visualizing phylogenetic trees and networks. Nucleic Acids Research 40: W573-W579. DOI: 10.1093/nar/gks485.
Carbonell-Moore M. 1996. Ceratocorys anacantha, sp. nov., a new member of the family Ceratocoryaceae Lindemann (Dinophyceae). Botanica Marina 39: 1-10. DOI: 10.1515/botm.1996.39.1-6.1.

Claparède E. \& Lachmann J. 1858. Études sur les infusoires et les rhizopodes. Mèmoires De L'institut National Génèvoise 6: 261-482.

Daugbjerg N., Hansen G., Larsen J. \& Moestrup Ø. 2000. Phylogeny of some of the major genera of dinoflagellates based on ultrastructure and partial LSU rDNA sequence data, including the erection of three new genera of unarmoured dinoflagellates. Phycologia 39: 302-317. DOI: $10.2216 /$ i0031-8884-39-4-302.1.

Dodge J. 1989. Some revisions of the family Gonyaulacaceae (Dinophyceae) based on a scanning electron microscope study. Botanica Marina 32: 275-298. DOI: 10.1515/botm.1989.32.4.275.

Escalera L., Italiano A., Pistocchi R., Montresor M. \& Zingone A. 2018. Gonyaulax hyalina and Gonyaulax fragilis (Dinoflagellata), two names associated with 'mare sporco', indicate the same species. Phycologia 57: 453-464. DOI: 10.2216/17-64.1.

Fensome R., Macrae R., Moldowan J., Taylor F. \& Williams G. 1996. The early Mesozoic radiation of dinoflagellates. Paleobiology 22: 329-338.

Fensome R.A., Taylor F.J.R., Norris G., Sarjeant W.A.S., Wharton D.I. \& Williams G.L. 1993. A classification of fossil and living dinoflagellates. Micropaleontology Special Publication 7: 1-245.

Gómez F. 2012. A checklist and classification of living dinoflagellates (Dinoflagellata, Alveolata). CICIMAR Oceánides 27: 65-140.

Graham H.W. 1942. Studies in the morphology, taxonomy, and ecology of the Peridiniales. Scientific Results Cruise VII Carnegie Biology Series 3: 1-129.

Guillard R.R.L. \& Ryther J.H. 1962. Studies of marine planktonic diatoms. I. Cyclotella nana Hustedt and Detonula confervacea Cleve. Canadian Journal of Microbiology 8: 229-239. DOI: 10.1139/m62-029.

Hall T.A. 1999. BioEdit: a user-friendly biological sequence alignment editor and analysis program for Windows 95/98/NT. Nucleic Acids Symposium Series 41: 95-98.

Hansen G., Moestrup Ø. \& Roberts K.R. 1997. Light and electron microscopical observations on Protoceratium reticulatum (Dinophyceae). Archiv Für Protistenkunde 147: 381-391. DOI: 10.1016/S00039365(97)80062-0.

Helenes J. 2000. Exochosphaeridium alisitosense n. sp.; a new gonyaulacoid dinoflagellate from the Albian of Baja California, Mexico. Micropaleontology 46: 135-142. DOI: 10.2113/46.2.135.

Hernandez-Becerril D.U., Rodriguez-Palacio M.C. \& Lozano-Ramirez C. 2010. Morphology of two bloom-forming or potentially toxic marine dinoflagellates from the Mexican Pacific, Heterocapsa pygmaea and Protoceratium reticulatum (Dinophyceae). Cryptogamie, Algologie 31: 245-254.

John U., Litaker R.W., Montresor M., Murray S., Brosnahan M.L. \& Anderson D.M. 2014. Formal revision of the Alexandrium tamarense species complex (Dinophyceae) taxonomy: the introduction of five species with emphasis on molecular-based (rDNA) classification. Protist 165: 779-804. DOI: 10.1016/j.protis.2014.10.001.

Katoh K. \& Standley D.M. 2013. MAFFT multiple sequence alignment software version 7: improvements in performance and usability. Molecular Biology and Evolution 30: 772-780. DOI: 10.1093/molbev/ mst010.

Kawai H. \& Nakayama T. 2015. Division Dinophyta. In: Syllabus of plant families: photoautotrophic eukaryotic algae (Ed. by W. Frey), pp. 29-49. Borntraeger Science Publishers, Stuttgart, Germany.

Kofoid C.A. \& Michener J.R. 1911. Reports on the scientific results of the expedition to the eastern tropical Pacific, in charge of Alexander Agassiz, by the U.S. Fish Commission steamer "ALBATROSS," from October 1904, to March, 1906, Lieut. L.M. Garrett, U.S.N., Commanding. XXII. New genera and species of Dinoflagellates. Bulletin of the Museum of Comparative Zoology at Havard College 54: 267-302.

Kokinos J.P. \& Anderson D.M. 1995. Morphological development of resting cysts in cultures of the marine dinoflagellate Lingulodinium polyedrum (= L. machaerophorum). Palynology 19: 143-166. DOI: 10.1080/01916122.1995.9989457.

Lebour M.V. 1925. The dinoflagellates of the northern seas. Marine Biological Association of the United Kingdom, Plymouth. 
Litaker W.R., Vandersea M.W., Kibler S.R., Reece K.S., Stokes N.A., Lutzoni F. M., Yonish B.A., West M.A., Black M.N.D. \& Tester P.A. 2007. Recognizing dinoflagellate species using ITS rDNA sequences. Journal of Phycology 43: 344-355. DOI: 10.1111/j.1529-8817.2007.00320.x.

Luo Z., Krock B., Mertens K.N., Nézan E., Chomérat N., Bilien G., Tillmann U. \& Gu H. 2017. Adding new pieces to the Azadinium (Dinophyceae) diversity and biogeography puzzle: non-toxigenic Azadinium zhuanum sp. nov. from China, toxigenic $A$. poporum from the Mediterranean, and a non-toxigenic $A$. dalianense from the French Atlantic. Harmful Algae 66: 65-78. DOI: 10.1016/j.hal.2017.05.001.

Medlin L., Elwood H.J., Stickel S. \& Sogin M.L. 1988. The characterization of enzymatically amplified eukaryotic 16S-like rRNA-coding regions. Gene 71: 491-499. DOI: 10.1016/0378-1119(88)90066-2.

Mertens K.N., Carbonell-Moore M.C., Pospelova V., Head M.J., Highfield A., Schroeder D., Gu H., Andree K.B., Fernandez M., Yamaguchi A. et al. 2018b. Pentaplacodinium saltonense gen. et sp. nov. (Dinophyceae) and its relationship to the cyst-defined genus Operculodinium and yessotoxin-producing Protoceratium reticulatum. Harmful Algae 71: 57-77. DOI: 10.1016/j. hal.2017.12.003.

Mertens K.N., Pospelova V. \& Head M.J. 2018a. Ceratocorys mariaovidiorum P.Salgado, S.Fraga, F.Rodríguez, P.Riobó \& I.Bravo is a junior synonym of Pentaplacodinium saltonense K.N.Mertens, M.C.CarbonellMoore, V.Pospelova \& M.J.Head. Notulae Algarum 45: 1-2.

Meunier A. 1910. Microplancton des mers de Barents \& de Kara. Duc d'Orléans Campagne Arctique de 1907. Bulens, Bruxelles. 355 pp.

Morquecho L., Góngora-González D.T. \& Okolodkov Y.B. 2009. Cysttheca relationships on Gonyaulacales and Peridiniales (Dinophyceae) from Bahía Concepción, Gulf of California. Acta Botánica Mexicana 88: 9-29. DOI: 10.21829/abm88.2009.310.

Orr R.J.S., Murray S.A., Stüken A., Rhodes L. \& Jakobsen K.S. 2012. When naked became armored: an eight-gene phylogeny reveals monophyletic origin of theca in dinoflagellates. PloS One 7: e50004. DOI: 10.1371 /journal.pone.0050004.

Paez-Reyes M. \& Head M.J. 2013. The cenozoic Gonyaulacacean dinoflagellate genera Operculodinium Wall, 1967 and Protoceratium Bergh, 1881 and their phylogenetic relationships. Journal of Paleontology 87: 786-803. DOI: $10.1666 / 12-103$.

Posada D. 2008. jModelTest: phylogenetic model averaging. Molecular Biology and Evolution 25: 1253-1256. DOI: 10.1093/molbev/ msn083.
Reinecke P. 1967. Gonyaulax grindleyi sp. nov.: a dinoflagellate causing a red tide at Elands Bay, Cape Province, in December 1966. South African Journal of Botany 33: 157-160.

Röder K., Hantzsche F.M., Gebühr C., Miene C., Helbig T., Krock B., Hoppenrath M., Luckas B. \& Gerdts G. 2012. Effects of salinity, temperature and nutrients on growth, cellular characteristics and yessotoxin production of Protoceratium reticulatum. Harmful Algae 15: 59-70. DOI: 10.1016/j.hal.2011.11.006.

Ronquist F. \& Huelsenbeck J.P. 2003. MrBayes 3: Bayesian phylogenetic inference under mixed models. Bioinformatics 19: 1572-1574. DOI: 10.1093/bioinformatics/btg180.

Sala-Pérez M., Alpermann T.J., Krock B. \& Tillmann U. 2016. Growth and bioactive secondary metabolites of arctic Protoceratium reticulatum (Dinophyceae). Harmful Algae 55: 85-96. DOI: 10.1016/j.hal.2016.02.004.

Saldarriaga J.F., Taylor F.J.R.M., Cavalier-Smith T., Menden-Deuer S. \& Keeling P.J. 2004. Molecular data and the evolutionary history of dinoflagellates. European Journal of Protistology 40: 85-111. DOI: 10.1016/j.ejop.2003.11.003.

Salgado P., Fraga S., Rodríguez F., Riobó P. \& Bravo I. 2018. Ceratocorys mariaovidiorum sp. nov. (Gonyaulacales), a new dinoflagellate species previously reported as Protoceratium reticulatum. Journal of Phycology 54: 126-137. DOI: 10.1111/jpy.12609.

Schiller J. 1937. Dinoflagellatae (Peridineae). Teil 2. In: Kryptogamen Flora (Ed. by L. Rabenhorst), pp. 1-589. Akademische Verlagsgesellschaft, Leipzig.

Scholin C.A., Herzog M., Sogin M. \& Anderson D.M. 1994. Identification of group- and strain-specific genetic markers for globally distributed Alexandrium (Dinophyceae). II. Sequence analysis of a fragment of the LSU rRNA gene. Journal of Phycology 30: 999-1011. DOI: 10.1111/ j.0022-3646.1994.00999.x.

Stamatakis A. 2006. RAxML-VI-HPC: maximum likelihood-based phylogenetic analyses with thousands of taxa and mixed models. Bioinformatics 22: 2688-2690. DOI: 10.1093/bioinformatics/btl446.

Swofford D.L. 2002. PAUP*: phylogenetic analysis using parsimony ${ }^{*}$ and other methods), version 4.0b10. Sinauer Associates, Sunderland, Massachusetts, USA.

Wołoszyńska J. 1929. Dinoflagellatae Polskiego Baltyku i blot nad Piasnica. Archivum Hydrobiologji I Rybactwa 3: 153-278. In Polish.

Zirbel M.J., Veron F. \& Latz M.I. 2000. The reversible effect of flow on the morphology of Ceratocorys horrida (Peridiniales, Dinophyta). Journal of Phycology 36: 46-58. DOI: 10.1046/j.1529-8817.2000.98088.x. 